\title{
Inorganic sulfur cycling in mid and lower Chesapeake Bay sediments
}

\author{
Eric E. Roden, Jon H. Tuttle \\ University of Maryland System, Center for Environmental and Estuarine Studies, Chesapeake Biological Laboratory,
} PO Box 38, Solomons, Maryland 20688-0038, USA

\begin{abstract}
Concentrations of dissolved and solid-phase inorganic sulfur compounds and sulfate reduction (SR) rates were measured in sediments along a lateral transect in the mesohaline region of the Chesapeake Bay estuary (USA). Areal SR rates varied seasonally from 2 to 10,5 to 60 , and 10 to $90 \mathrm{mmol} \mathrm{m} \mathrm{m}^{-2} \mathrm{~d}^{-1}$ in deep channel, channel slope and western flank sediments respectively, and with temperature according to an apparent activation energy of ca $83 \mathrm{~kJ} \mathrm{~mol}^{-1}$ March through November integrated SR rates were 1.3, 5.3 and $7.3 \mathrm{~mol} \mathrm{~m}^{-2} \mathrm{yr}^{-1}$ at the 3 locations respectively. Summer SR rates in other mid-bay central channel and lower bay sediments were comparable to the highest rates found along the mid-bay transect. Sulfate reduction was maximal in the top 2 to $4 \mathrm{~cm}\left(0.2\right.$ to $\left.2 \mathrm{mmol}^{-1} \mathrm{~d}^{-1}\right)$ of sediment and decreased several-fold with depth to $12 \mathrm{~cm}$ in both mid-and lower bay sediments. Mid-bay central channel sediments underlying anoxic bottom water during the summer exhibited high concentrations ( 1 to $5 \mathrm{mM}$ ) of dissolved sulfide (DS), whereas bioturbated flank sediments had 5- to 10-fold lower DS concentrations $(0.1$ to $1 \mathrm{mM})$. In lower bay sediments, DS concentrations were $<0.1 \mathrm{mM}$ in the upper $12 \mathrm{~cm}$ despite intense $\mathrm{SR}\left(25\right.$ to $\left.100 \mathrm{mmol} \mathrm{m}^{-2} \mathrm{~d}^{-1}\right)$. Solid phase reduced sulfur concentrations in mid-and lower bay sediments were not correlated with SR rates. Comparison of annual SR with reduced sulfur burial indicated that $<30 \%$ of total sulfide production is permanently retained in mid-bay sediments. A similar fraction of sulfide retention is expected to occur in lower bay sediments. Our results indicate that sulfur cycling accounts for a substantial portion of carbon mineralization and oxygen consumption over a large area of the mid-and lower Chesapeake Bay benthos.
\end{abstract}

\section{INTRODUCTION}

The importance of inorganic sulfur transformations in the early diagenesis of coastal marine sediments is well recognized. In such sediments, a significant fraction $(\geq 20 \%)$ of carbon mineralization and oxygen uptake is coupled to sulfate reduction (SR) and sulfide reoxidation respectively, rather than to aerobic respiration (Jørgensen 1977, 1982, Howes et al. 1984, Parkes \& Buckingham 1986, Mackin \& Swider 1989, Sampou \& Oviatt 1991). The fraction of sediment carbon metabolism mediated by SR covaries with the total rate of mineralization, which is a function of carbon loading to sediments (Jørgensen 1983, Nedwell 1984. Capone \& Kiene 1988). Therefore, the quantitative significance of SR in carbon cycling and oxygen balance is maximal in highly productive environments such as shallow-water subtidal and salt marsh sediments (Howarth 1984).
The high productivity and shallowness of the Chesapeake Bay estuary (USA) make it an especially relevant environment in which to assess sediment sulfur metabolism and its quantitative role in carbon cycling and oxygen balance. In this paper we consider dissolved and solid-phase inorganic sulfur content and SR rates on a seasonal basis (April through November) in sediments along a lateral transect in the mesohaline region of the Chesapeake Bay (Fig. 1). We also report data collected during the summer and winter at 3 other locations along the deep central channel of the midbay, and during the summer at 3 locations in the lower bay region. Our objectives were to assess the spatial variability of summer $\mathrm{SR}$ rates along the central axis of the mid-and lower regions of Chesapeake Bay; to quantify the magnitude and seasonal variation of SR in sediments along the mid-bay transect; and to compare sulfur chemistry in mid-bay central channel sediments, which underly anoxic bottom waters during the sum- 


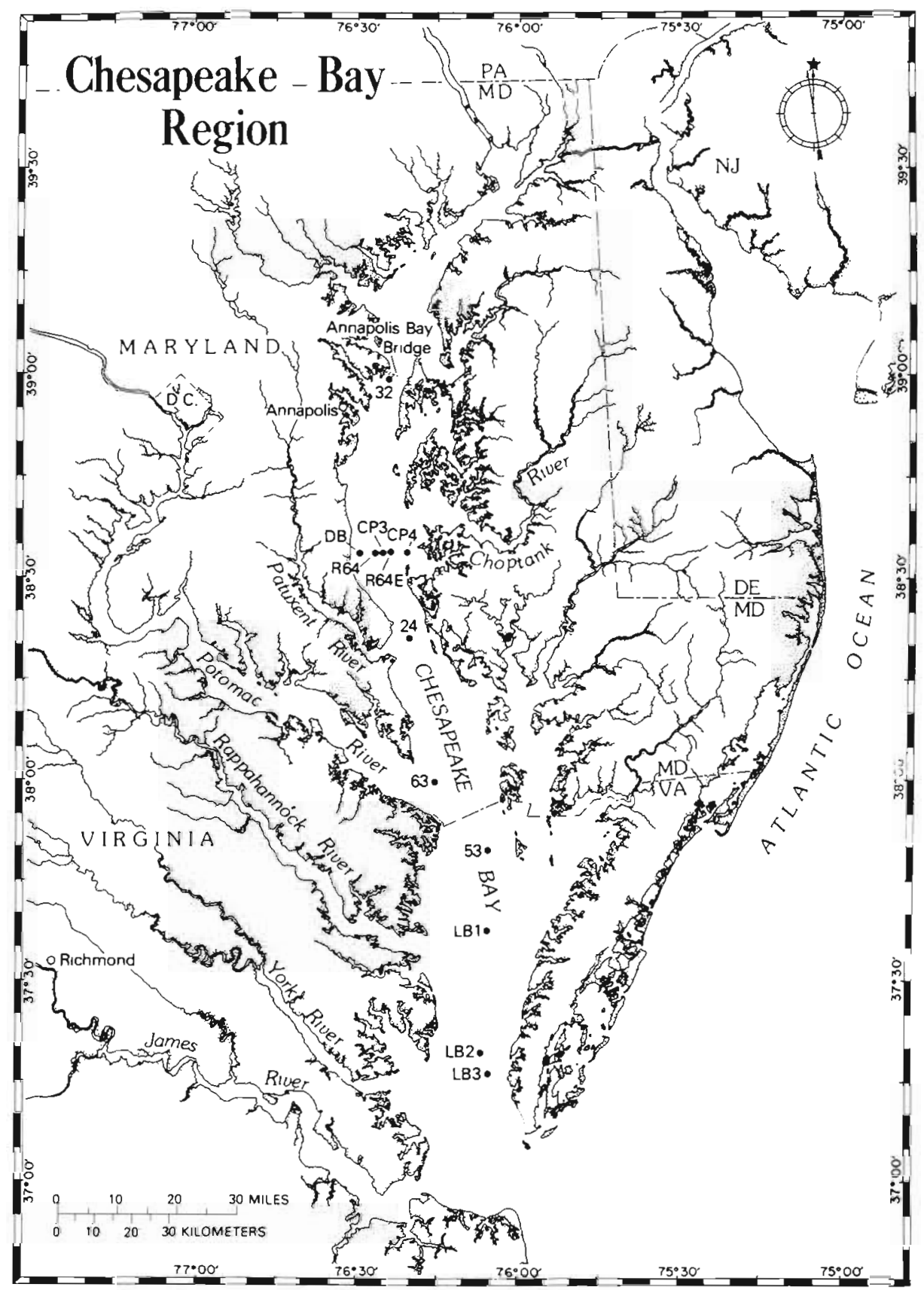

Fig. 1. Station locations in the midand lower Chesapeake Bay

mer, with that in sediments on the mid-bay flank and in the lower bay, where bottom waters are typically well-oxygenated.

\section{MATERIALS AND METHODS}

Station locations and descriptions. Sediments were sampled along a lateral transect in the mesohaline region of Chesapeake Bay (Fig. 1). Stns CP3 (25 m depth) and R64 (16 m) represent central channel bottom and western slope sediments respectively. Sediments at these stations typically underlie hypoxic or anoxic bottom water dunng the summer, a condition which precludes macrofaunal activity during the period of highest temperature and microbial activity. In contrast. the bottom water at Stn DB (10 m depth) on the western flank of the mid-bay is usually well oxygenated and the sediments are colonized by a mixed community of bivalves and polychaetes. Bottom water temperatures vaned sinusoidally from a maximum of 25 to $26^{\circ} \mathrm{C}$ in the late summer to a munimum of 1 to $2^{\circ} \mathrm{C}$ during late winter 

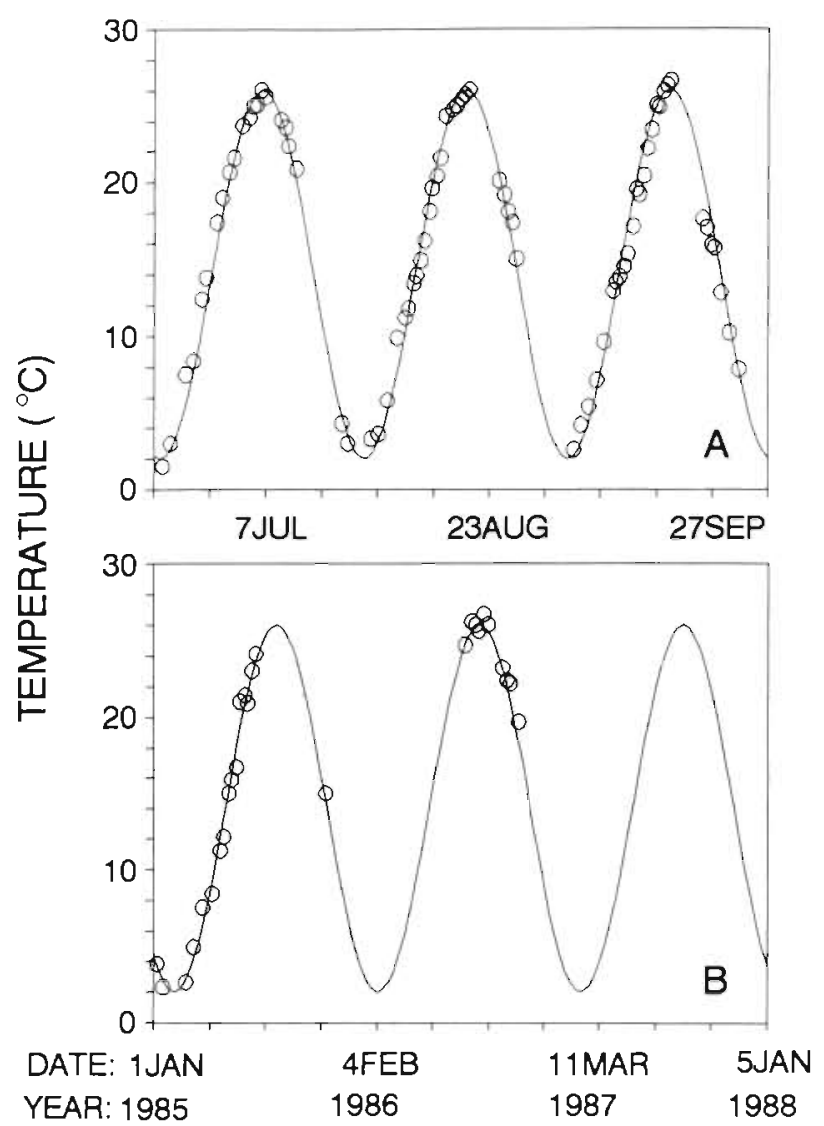

Fig. 2. Annual variation of bottom water temperature $\left(T,{ }^{\circ} \mathrm{C}\right)$ at Stns R64 (A) and DB (B). Measurements from this study and Boynton et al. (1988) are combined. The data were fit to the equation (Rice 1986) $\mathrm{T}(t)=T_{1}+0.5\left(T_{2}-T_{1}\right) \mid 1-\cos (2 \pi t / 365-$ $2 \pi Q / 365$ ) , where $t=$ time (Julian date); $T_{1}=$ annual minimum temperature; $T_{2}=$ annual maximum temperature; and $Q=$ Julian date of minimum temperature. Values for $T_{1}, T_{2}$, and $Q$ are given in Table 2

(Fig. 2). Salinity varied from 14 to 22 and 12 to $18 \mathrm{~g} \mathrm{~kg}^{-1}$ in central channel and western flank bottom waters respectively, with minima occurring in the spring (Boynton et al. 1988). Bottom water sulfate concentration followed salinity variations, ranging from 12 to 18 and 10 to $14 \mathrm{mM}$ in central channel and western flank bottom waters respectively.

On 2 occasions (February and July 1986) sediments ( 0 to $15 \mathrm{~cm}$ ) from 3 other stations along the central axis of the mid-bay $(32,24$ and 53; Fig. 1) were sampled for sulfate concentrations and reduction rates. These measurements were also made at a site on the eastern flank of the mid-bay (Stn CP4) in May 1986, at a location in the mouth of the Potomac River (Stn 63) in July 1987, and at 3 locations in the lower bay region (Stns LB1, LB2 and LB3) in July 1987 (Fig. 1). Bottom water salinity and sulfate concentration at the additional mid-bay sites were similar to those along the lateral transect. Higher salinity (25 to $30 \mathrm{~g} \mathrm{~kg}^{-1}$ ) and sulfate
(20 to $25 \mathrm{mM}$ ) levels were present in lower bay waters. Lower bay sediments were less porous ( $\phi=0.5$ to 0.7 ) and had a lower dry weight organic matter content ( 2 to $5 \%$ ) than mid-bay sediments $\phi=0.85$ to 0.95 ; organic matter $=6$ to $12 \%$ ).

Sediment pore water sampling. Sediments at Stns 24, 32 and 53 were sampled with a gravity corer which held a $7.6 \mathrm{~cm}$ ID polycarbonate liner. At all other stations, sediments were collected with a Bouma box corer $\left(136 \mathrm{~cm}^{2}\right.$ area, ca $25 \mathrm{~cm}$ depth). Subcores for determination of pore water constituents were removed from box cores with $7.3 \mathrm{~cm}$ ID polycarbonate tubes, sectioned at 1 to $2.5 \mathrm{~cm}$ intervals, and the sediments loaded into $50 \mathrm{ml}$ plastic centrifuge tubes. Sediments obtained from gravity cores were held frozen in the centrifuge tubes prior to processing in the laboratory. Sediments collected from box cores were sectioned inside an $\mathrm{N}_{2}$-filled glove bag, or quickly sectioned into centrifuge tubes while gassing with $\mathrm{N}_{2}$. Pore fluids were separated immediately by centrifugation for 20 to $40 \mathrm{~min}$ at ca $2000 \times \mathrm{g}$. After centrifugation, the supernatant was drawn into a $\mathrm{N}_{2}$-gassed syringe and filtered through an in line GF/C glass fiber filter into preweighed vials containing $0.5 \mathrm{ml}$ of $10 \%$ zinc acetate. Duplicate 100 to $500 \mu \mathrm{l}$ portions of the resulting $\mathrm{ZnS}$ suspension were assayed for sulfide by the methylene blue colorometric method described by Trüper \& Schlegel (1964). Calibration curves for the colorometric reagents were prepared periodically using sodium sulfide solutions standardized by iodometric titration. The pore fluid samples were then filtered again through GF/C filters into clean vials for storage until sulfate analysis. Sulfate concentrations in diluted pore fluid samples were determined with a Dionex (Sunnyvale, CA, USA) 2020i ion chromatograph operated at $30 \mu \mathrm{S}$ output. The precision of replicate sulfate analyses within the concentration range of 0.1 to $0.5 \mathrm{mM}$ was ca $5 \%$.

Sulfate reduction. SR rates were determined in intact sediment samples by the ${ }^{35} \mathrm{~S}$ radiotracer methods of Jørgensen (1978a). Gravity cores were sampled at $2.5 \mathrm{~cm}$ intervals by quickly inserting cut-off plastic syringes $(10 \mathrm{ml})$ into the sediment after peeling duct tape away from pre-drilled sampling ports in the core liner. All other determinations were made using $2.5 \mathrm{~cm}$ ID (15 cm length) vertical subcores taken from box cores. Syringe subcores were sealed with serum stoppers through which the radiotracer solution was injected into the sediment along a line. Vertical subcores had silicone-sealed injection ports through which the radiotracer was line-injected at 1 or $2 \mathrm{~cm}$ intervals. The radioactivity added ranged from 1 to $5 \mu \mathrm{Ci}$ of carrier-free $\mathrm{Na}_{2}{ }^{35} \mathrm{SO}_{4}$ (ICN Radiochemicals, Irvine, CA, USA) in 10 to $50 \mu \mathrm{l}$ of distilled water. After incubation ( 4 to $24 \mathrm{~h}$ ) in a cooler of bottom water at the in situ temperature, activity was terminated by freezing the cores. 
Reduced ${ }^{35} \mathrm{~S}$ was recovered in different operationally defined fractions by selective sulfide distillations under anaerobic conditions. Dissolved sulfide $\left(\mathrm{DS}_{i}=\mathrm{S}^{-2}+\mathrm{HS}^{-}\right.$ $+\mathrm{H}_{2} \mathrm{~S}$ ) was driven off by slurrying ca $10 \mathrm{ml}$ wet sediment with $20 \mathrm{ml}$ of $0.1 \mathrm{M}$ phosphate buffer pH 6.5 (Jørgensen $\&$ Fenchel 1974). Solid phase acid-volatile sulfide (AVS; = iron monosulfides) was subsequently released by addition of $20 \mathrm{ml}$ of $6 \mathrm{~N} \mathrm{HCl}$. In most cases, the acid solution contained $1 \mathrm{M} \mathrm{TiCl} / 3$ to retard oxidation of sulfide during the distillation procedure (Albert 1984). Nonacidvolatile sulfide (NAVS $;$ = elemental sulfur and pyrite) was evolved in a boiling solution of $1 \mathrm{M}$ reduced chromium $(30 \mathrm{ml})$ and concentrated $\mathrm{HCl}(15 \mathrm{ml})$ (Zhabina \& Volkov 1978). During each distillation, the hydrogen sulfide $\left(\mathrm{H}_{2} \mathrm{~S}\right)$ produced was carried by an oxygen-free $\mathrm{N}_{2}$ stream into a $10 \%(\mathrm{w} / \mathrm{v})$ zinc acetate trap $(10,20$ and $100 \mathrm{ml}$ for dissolved, acid-volatile, and nonacid-volatile sulfide distillations respectively), where it precipitated as ZnS. One to four drops of antifoam B (Baker Chemicals, NJ, USA) was added to each trap prior to distillation to prevent excessive foaming. Two $\mathrm{ml}$ portions of the trap solutions were mixed with $7 \mathrm{ml}$ Instagel scintillation cocktail (Packard Instrument Co., Downers Grove, IL, USA) and radioactivity determined with a liquid scintillation counter (Packard Model 4330) operated in the DPM mode and with quench correction by the external standard channelsratio method. On 2 occasions (August and November 1987), all the above reduced sulfur fractions were separated from $\mathrm{R} 64$ and $\mathrm{DB}$ sediments. Other SR determinations were made either by separate AVS and NAVS distillations, or by acidic reduced chromium distillation alone, which yields total reduced sulfur.

SR rates were calculated as the product of the fraction of added radioactivity recovered as reduced label per unit time and the whole sediment sulfate concentration at the appropriate depth in the sediment. All SR rates were corrected for time-zero blanks determined for each reduced sulfur distillation procedure. The time-zero blanks were determined by adding a known quantity of ${ }^{35} \mathrm{SO}_{4}{ }^{2-}$ to $10 \mathrm{ml}$ of sediment and immediately beginning the distillation. The total reduced sulfur distillation had the highest apparent carry-over of unreduced label into the trap solution, $0.145 \pm$ $0.049 \%$ of total label added $(\mathrm{n}=12)$. The other distillations gave blanks of $<0.05 \%$

A time course experiment was conducted with intact cores collected at Stns CP3 and DB in June at $20^{\circ} \mathrm{C}$. Duplicate cores were injected with ${ }^{35} \mathrm{SO}_{4}{ }^{2-}$ (9 depth horizons within the upper $15 \mathrm{~cm}$ ) and incubated for 0 . 2,8 or $16 \mathrm{~h}$ before freezing. Accumulation of reduced ${ }^{35} \mathrm{~S}$ in the cores was linear over the $16 \mathrm{~h}$ time course $\left(\mathrm{r}^{2}=0.92\right.$ and 0.95 for the CP3 and DB cores respectively). The time-zero cores yielded blanks comparable to those determined as described above.
The relationship between areal SR rate and seasonal temperature variation was assessed by fitting the rate data to the Arrhenius equation:

$$
\ln r(T)=A-E_{\mathrm{a}}(R T)^{-1}
$$

where $r(T)=$ areal SR rate $\left(\mathrm{mmol} \mathrm{m} \mathrm{m}^{-2} \mathrm{~d}^{-1}\right)$ at temperature $T(K) ; A=$ constant; $E_{\mathrm{a}}=$ apparent activation energy $\left(\mathrm{kcal} \mathrm{mol}^{-1}\right), R=$ gas constant $=8.314 \times 10^{-3} \mathrm{~kJ}$ $\mathrm{mol}^{-1} \mathrm{~K}^{-1}$. March through November integrated SR rates were estimated by combining the time/ temperature function $T(t)$ for each station (see Fig. 2) with the results of the Arrhenius fits. The time/ temperature relationship for Stn R64 was used to predict integrated SR rates at Stn CP3.

Reduced sulfur pool sizes. Pool sizes of the various reduced sulfur fractions were determined by colorometric analysis of the $\mathrm{ZnS}$ content of the sulfide traps (as described above). The precision of this analysis was ca $10 \%$. Concentrations of DS determined by distilling frozen sediment sections with phosphate buffer ranged from 70 to $100 \%$ of those measured in the pore fluid from parallel cores. Recoveries of reagent grade FeS (Aldrich Chemicals) by $6 \mathrm{~N} \mathrm{HCl} / 1 \mathrm{M} \mathrm{TiCl}_{3}$ distillation and $\mathrm{FeS}_{2}$ (Mallincrodt Chemicals) by reduced chromium distillation were $97 \pm 4 \%(n=3)$ and $100 \pm$ $6 \%(n=6)$ respectively.

Sulfate diffusion coefficient. A sediment diffusion coefficient for DS was derived from those measured for sulfate at Stns R64 and DB during August (0.43 and $0.50 \mathrm{~cm}^{2} \mathrm{~d}^{-1}$ respectively) by the ${ }^{35} \mathrm{SO}_{4}{ }^{2-}$ instantaneous source technique as described by Jørgensen (1978b). These coefficients were corrected for the more rapid diffusion of DS compared to sulfate by the ratio of the self-diffusion coefficients for $\mathrm{HS}^{-}$and $\mathrm{SO}_{4}{ }^{2-}(1,7)$, and were adjusted for temperature according to the Einstein-Stokes relation (Li \& Gregory 1974). At the $\mathrm{pH}$ of mid-bay sediments $(7.3$ to 7.9 ; J. Cornwell unpubl.), HS $^{-}$would account for the major portion $(67$ to $89 \%$ ) of total DS. Thus, the correction factor of 1.7 is most appropriate for mid-bay sediments.

Particulate organic carbon. The particulate organic carbon (POC) content of mid-bay sediments was determined by CHN analysis of 1 to $2 \mathrm{mg}$ of dried, ground sediment. After grinding, the dried sediments were transferred to small plastic weigh boats, placed in an acid-fume chamber overnight to drive off carbonates, and redried for several hours at $80^{\circ} \mathrm{C}$ before being weighed out for CHN analysis.

Depth profiles of sediment POC content at Stns R64, DB and CP3 were fitted by non-linear least squares regression to the equation:

$$
G(x)=\left\{G_{0}-G_{L}\right) \exp (-\alpha x)+G_{L}
$$

where $G(x)=$ dry weight POC content of sediment particles at depth $x_{i} G_{0}=$ dry weight POC content of 
sediment particles at the sediment surface; $G_{L}=$ dry weight POC content of sediment particles at lower boundary depth $L$, below which no change in POC content of sediment particles was observed; and $\alpha$ is an attenuation constant. The depth distribution of degradable POC was estimated by:

Degradable POC $(x)=\left(G_{0}-G_{L}\right) \exp (-\alpha x)$ (2)

following the '1-G' approach described by Murray et al. (1978). To calculate the depth-integrated pool of degradable POC, Eq. 2 was combined with sediment porosity distributions and the result integrated trapezoidally over $0.5 \mathrm{~cm}$ depth increments

Reactive iron. The pool size of reactive (toward sulfide) ferric iron in R64 sediments was estimated from June 1988 measurements of oxalate-extractable $\mathrm{Fe}$ (J. Cornwell unpubl.). The iron content of the AVS pool in each depth interval (measured separately) was subtracted from the total oxalate extractable iron pool to correct for AVS dissolved during oxalate extraction. The reactive fraction of oxalate-extractable iron was estimated according to Aller (1980a), i.e. the concentration at depth was assumed to represent the nonreactive fraction, and this value was subtracted from the higher concentrations near the sediment surface. This procedure is analogous to the ' $1-G$ ' approach for estimating degradable POC distributions from depth profiles of POC content.

\section{RESULTS}

\section{Areal rates of sediment SR}

Depth-integrated (0 to $12 \mathrm{~cm}$ ) SR rates in sediments at Stns R64, DB and CP3 along the mid-bay transect varied seasonally from 5 to 60,10 to 90 and 2 to $10 \mathrm{mmol} \mathrm{m}^{-2} \mathrm{~d}^{-1}$ respectively. The rate at Stn CP4 in May $\left(16 \mathrm{mmol} \mathrm{m}^{-2}\right.$ $\mathrm{d}^{-1}$ ) was similar to that determined at Stn DB at the same time of year. Summer rates at mid-bay channel Stns 24 and 32 (Table 1) were comparable to those at Stns R64 and DB, whereas summer rates at the southern end of the mid-bay deep channel (Stn 53) and at the Potomac River mouth (Stn 63) were somewhat lower. Winter rates at Stns 24 and 53 were low and comparable to those at Stns CP3 and R64 during early spring, whereas a relatively high winter SR rate was found at Stn 32 . The SR rates for $\operatorname{Stn} 24$ reported here are similar in magnitude to previous measurements at this station made during 1984 and 1985 (J. Tuttle \& E. Roden unpubl.).
Lower bay sediments exhibited summer SR rates comparable to or greater than those in the mid-bay (Table 1). Rates found at Stns LB1 and LB3 were similar to those recently measured at a site off the mouth of the York River (M. Marvin \& D. Capone unpubl.). The highest areal SR rate $\left(126 \mathrm{mmol} \mathrm{m}^{-2} \mathrm{~d}^{-1}\right)$ we observed in this study was at Stn LB2.

\section{Seasonal variation of SR rates in the mid-bay}

Maximum areal SR rates in mid-bay transect sediments occurred during the period June through August (Fig. 3); rate minima, similar in magnitude, were observed at Stns R64 and DB during April and November. Arrhenius plots of the data (Fig. 3, insets) yielded similar apparent activation energy $\left(E_{a}\right)$ estimates (ca $83 \mathrm{~kJ}$ $\mathrm{mol}^{-1}$; average $Q_{10}$ of 3.3 between 5 and $25^{\circ} \mathrm{C}$ ) for the 3 stations. The solid lines in Fig. 3 (main panels) are rates predicted by combining the time/temperature function $T(t)$ for each station (Fig. 2) with the corresponding Arrhenius fit parameters (Table 2). The predicted rates were integrated over $1 \mathrm{~d}$ intervals, yielding March through November integrated SR rates of 5.3, 7.3 and $1.3 \mathrm{~mol} \mathrm{~S} \mathrm{~m}^{-2} \mathrm{~d}^{-1}$ at Stns R64, DB and CP3 respectively.

\section{Depth distribution of SR rates}

SR rates decreased 5-to 10 -fold with depth in the topmost $12 \mathrm{~cm}$ of all sediments examined in the midand lower bay. Measurements made to a depth of $40 \mathrm{~cm}$ in May 1986 indicated that $70 \pm 10$ (range of 2 cores) and $89 \pm 4 \%$ (range of 2 cores) of total activity 


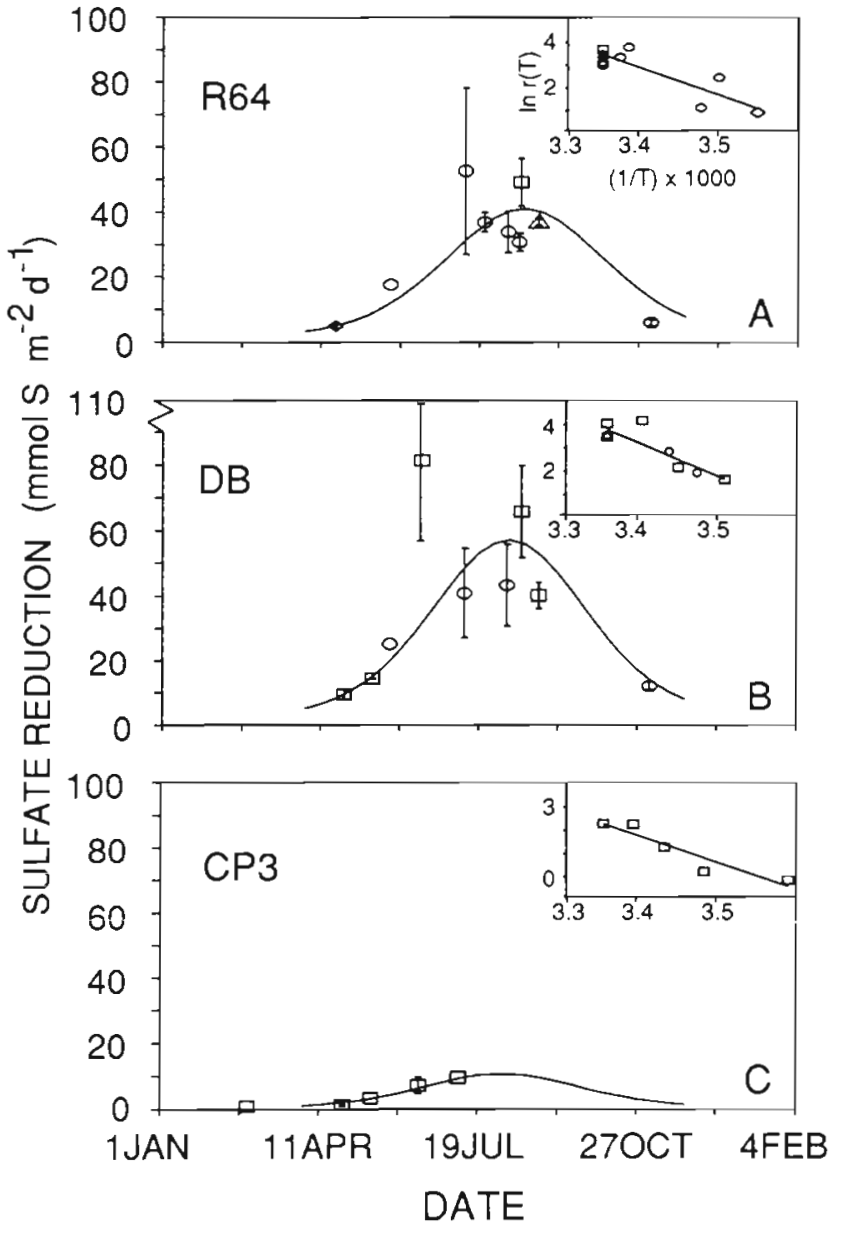

Fig. 3. Depth-integrated $(0-12 \mathrm{~cm})$ sulfate reduction (SR) rates at Stns R64, DB and CP3. (口) 1986; (O) 1987; (○) 1989; $(\triangle) 1986$ R64E. Each symbol represents mean ( \pm range or SD) of 2 to 6 replicate cores. Solid lines are SR rates predicted by combining Arrhenius plot (insets) results and time/ temperature relationships for each station (Table 2)

was accounted for in the upper $12 \mathrm{~cm}$ of sediment at Stns CP3 and DB respectively (data not shown). Because the decrease in SR with depth was usually more distinct in R64 (Fig. 4) compared to DB (Fig. 5) sediments, we expect that a similarly large fraction of total SR in R64 sediments occurred within the 0 to $12 \mathrm{~cm}$ horizon. Therefore, restricting our routine measurements to $12 \mathrm{~cm}$ depth probably led to only a minor underestimation of areal SR at Stns R64 and DB and at other stations where relatively high rates of sulfate reduction occurred.

\section{Dissolved sulfide distributions}

Distinct seasonal variations in pore fluid distributions were observed at Stns R64 and DB. DS was not detected in the upper few $\mathrm{cm}$ of R64 sediments during the spring (Fig. 6). During summer anoxia, however, high levels of DS (0.2 to $2 \mathrm{mM}$ ) accumulated in surface sediments, indicating the potential for direct exchange of sulfide from sediments to bottom waters (Roden \& Tuttle 1992). With the reappearance of oxygen in midbay bottom waters in the autumn, DS disappeared from the topmost $2 \mathrm{~cm}$ of sediment.

Stn DB sediments exhibited very low DS levels throughout the topmost $15 \mathrm{~cm}$ in May and June (Fig. 7). Maximum DS concentrations $(\leq 50 \mu \mathrm{M})$ were at least 10 times less than those at R64 (Fig. 6). Substantially higher DS levels (0.5 $\mathrm{mM})$ were found at depth (12 cm) in eastern flank (CP4) sediments in May (data not shown), but these were still 5 -fold less than DS concentrations at depth in R64 sediments. Pore water DS concentrations remained much lower ( $<1 \mathrm{mM}$ ) at $\mathrm{DB}$ than at $R 64$, even during periods of intense SR in the summer (Fig. 5). By November, DS concentrations at Stn $\mathrm{DB}$ had decreased to $<0.1 \mathrm{mM}$, but remained higher than during the spring in the upper $10 \mathrm{~cm}$ of sediment.

\section{Solid-phase reduced sulfur distributions}

Total solid-phase reduced sulfur concentrations (ca $1 \%$ of sediment dry weight below $4 \mathrm{~cm}$ depth) were similar in sediments along the mid-bay lateral transect (see Table 5), and comparable to those found in other fine-grained coastal sediments (Berner \& Westrich 1985, Chanton et al. 1987). In contrast, the relative abundance of acid-volatile sulfide (AVS) versus partially oxidized, non-acid-volatile sulfide (NAVS) differed among sediments along the transect, decreasing from a ratio of ca $1: 3$ at Stn R64 (Fig. 8A, B) to $1: 5$ at Stn CP3 (data not shown) and $1: 10$ at Stn DB (Fig. 8C, D). The low AVS abundance in flank station sediments probably reflects the oxidizing influence of macrofaunal activity, a conclusion supported higher redox potentials (Kemp et al. 1991, W. Boynton unpubl.) and lower DS concentrations (Fig. 7) relative to channel sediments (Fig. 6). Likewise, the higher AVS:NAVS ratio in R64 compared to CP3 sediments is likely related to more reducing conditions (lower redox potentials and higher DS concentrations) and more intense rates of sulfide formation found at R64 (Fig. 3).

Substantial seasonal changes in AVS abundance, particularly from spring to summer, were observed in the topmost $4 \mathrm{~cm}$ of R64 and DB sediments (Fig. 8A, C), whereas few such changes in NAVS were evident (Fig. 8B, D). The lack of significant NAVS change was probably due to core-to-core variability as well as the large background pool of NAVS in mid-bay sediments. We have interpreted changes in AVS abundance quanti- 
Table 2. Time/temperature function parameters $\left(T_{1}, T_{2}, Q\right)$, Arrhenius rate function parameters for areal sulfate reduction (SR) $\left(A, E_{\mathrm{d}}\right)$, and March through November ( $240 \mathrm{~d}$ interval) integrated $\mathrm{SR}$ rates ( $\Sigma \mathrm{SR}$ ) at stations along a mid-bay lateral transect. Parameters are described in Fig. 2 and in the text. $r^{2}$ : Least squares regression fit of the rate data to the Arrhenius equation (see Fig. 3 , insets)

\begin{tabular}{|lccccccc|}
\hline Station & $\begin{array}{c}T_{1} \\
\left({ }^{\circ} \mathrm{C}\right)\end{array}$ & $\begin{array}{c}T_{2} \\
\left({ }^{\circ} \mathrm{C}\right)\end{array}$ & $\begin{array}{c}Q \\
(\text { Julian date })\end{array}$ & $A$ & $\begin{array}{c}E_{\text {a }} \\
\left(\mathrm{kJ} \mathrm{mol}^{-1}\right)\end{array}$ & $\mathrm{r}^{2}$ & $\begin{array}{c}\Sigma \mathrm{SR} \\
\left(\mathrm{mol} \mathrm{m} \mathrm{m}^{-2}\right)\end{array}$ \\
\hline R64 & 26 & 2 & 46 & 36.1 & 80.3 & 0.76 & 5.30 \\
DB & 26 & 2 & 37 & 39.0 & 86.6 & 0.76 & 7.29 \\
CP3 & 26 & 2 & 33 & 34.5 & 80.8 & 0.88 & 1.38 \\
\hline
\end{tabular}

ences were probably due to sample variability rather than to seasonal accumulation. The latter assumption is based on the finding that sulfide production rates below $4 \mathrm{~cm}$ depth were too low to support the magnitude of AVS accumulation calculated from concentration differences, and that AVS (and NAVS) concentrations failed to increase systematically with depth below $4 \mathrm{~cm}$. The latter observation strongly suggests that solid-phase reduced sulfur accumulation was limited primarily to the top $4 \mathrm{~cm}$ of sediment.

tatively (Table 3 ) with the caveats that: (1) estimates of reduced sulfur storage are subject to large uncertainties due to sample variability and, thus, represent first approximations only; and (2) although we observed some significant AVS differences below $4 \mathrm{~cm}$ depth (particularly at Stn R64) on different sampling dates, these differ-

SULFATE REDUCTION (mmol liter ${ }^{-1} \mathrm{~d}^{-1}$ )

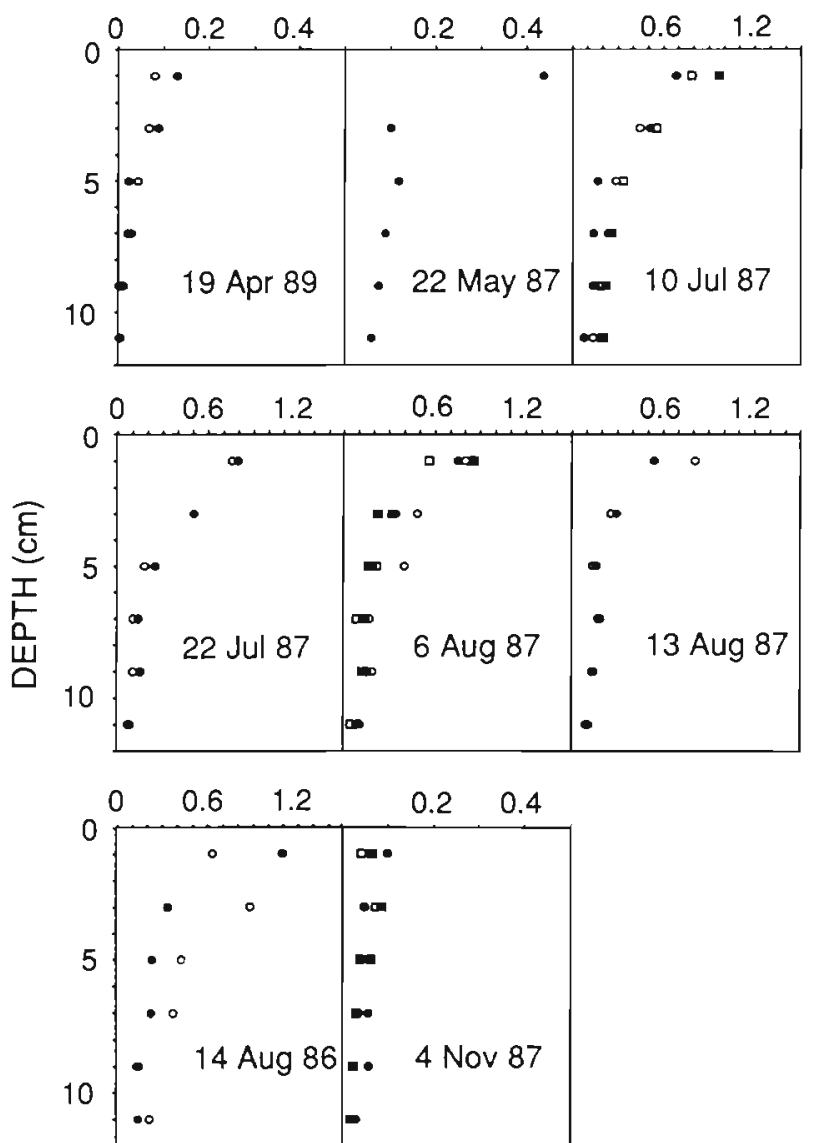

Fig. 4. Sulfate reduction rates in R64 sediments. Each symbol represents an individual rate measurement in a core segment; like symbols represent measurements made with the same whole core
Between April and August, calculated AVS accumulation within the upper $4 \mathrm{~cm}$ of sediment was 0.65 and $0.61 \mathrm{~mol} \mathrm{~m}^{-2}$ at Stns $\mathrm{R} 64$ and DB respectively (Table 3). AVS continued to accumulate $(0.24 \mathrm{~mol}$ $\mathrm{m}^{-2}$ ) in the 2 to $4 \mathrm{~cm}$ horizon of R64 sediments from August to November, but decreased $\left(0.25 \mathrm{~mol} \mathrm{~m}^{-2}\right)$ in surface $(0$ to $2 \mathrm{~cm}) \mathrm{DB}$ sediments during the same period.

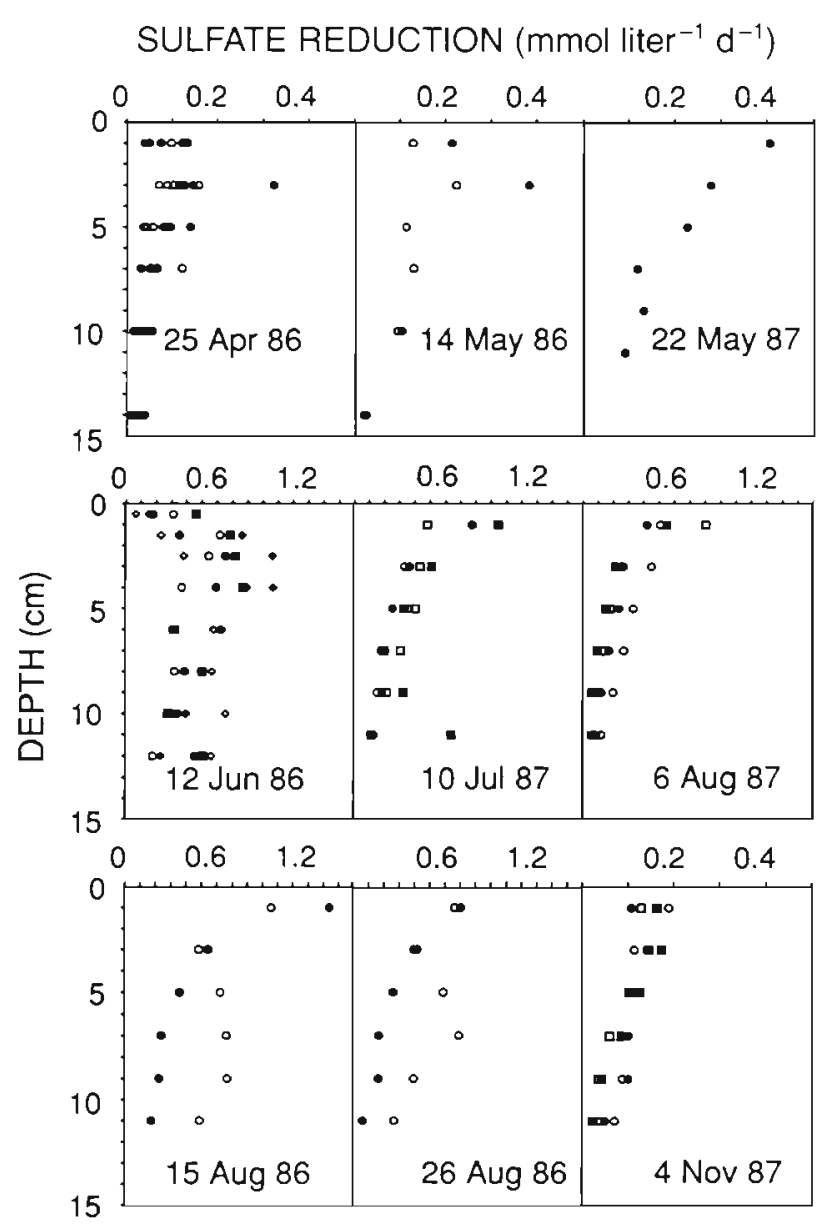

Fig. 5. Sulfate reduction rates in $\mathrm{DB}$ sediments. Symbols as in Fig. 4 
DISSOLVED SULFIDE (mM)

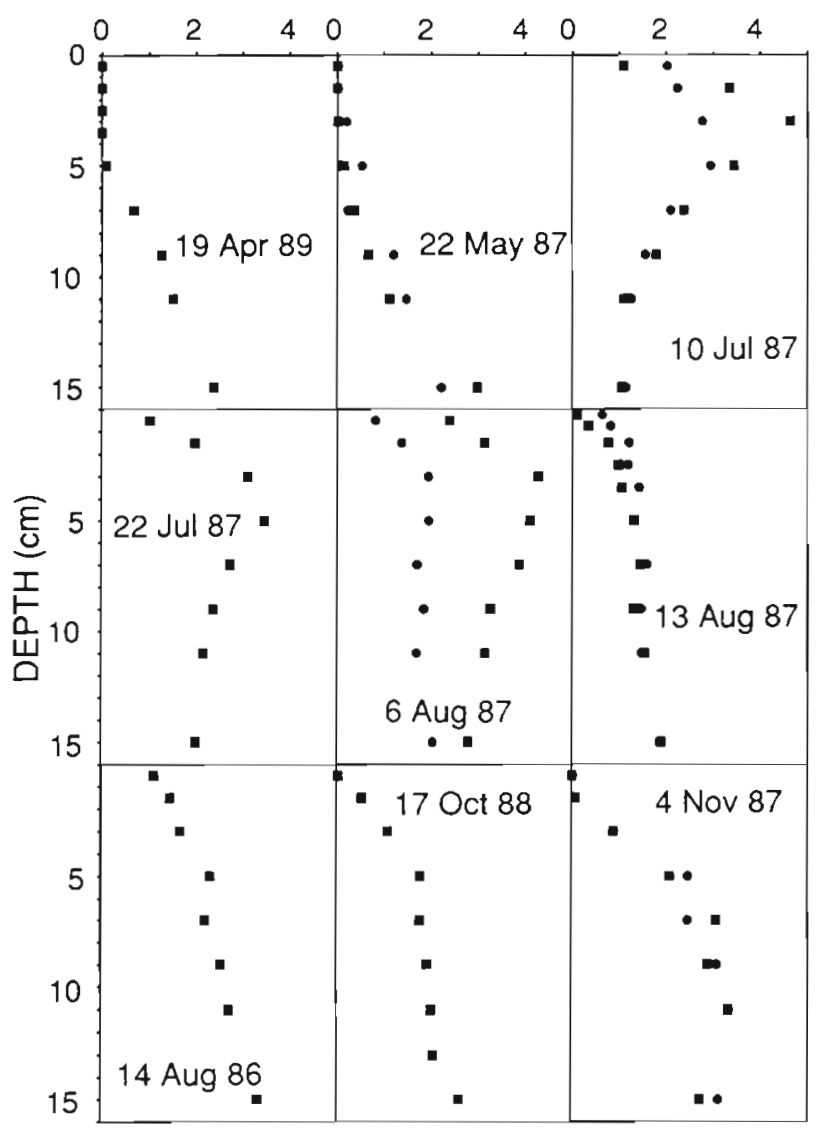

Fig. 6. Pore fluid dissolved sulfide concentrations in R64 sediments. Different symbols in the same panel refer to replicate cores

\section{End products of ${ }^{35} \mathrm{SO}_{4}{ }^{2-}$ reduction}

The recovery of reduced ${ }^{35} \mathrm{~S}$ as partially oxidized, non-acid-volatile reduced sulfur compounds (NAV ${ }^{35} \mathrm{~S}$ ) differed in sediments along the mid-bay transect. It is important to note that these cores were extracted for $\mathrm{AV}^{35} \mathrm{~S}$ with an acidic $\mathrm{TiCl}_{3}$, thus eliminating the possibility of $\mathrm{H}_{2}{ }^{35} \mathrm{~S}$ reoxidation during the extraction (Albert 1984). At R64 in April, 20 to $40 \%$ of total reduced ${ }^{35} \mathrm{~S}$ formed in the topmost $2 \mathrm{~cm}$ of sediment was recovered as $\mathrm{NAV}^{35} \mathrm{~S}$ (Fig. 9A), whereas at DB in June, 35 to $70 \%$ of reduced ${ }^{35} \mathrm{~S}$ found in this interval was in the NAVS fraction (Fig. 9D). The corresponding range for Stn CP3 sediments in June was 40 to $60 \%$.

When central channel bottom waters were anoxic (August), less than $10 \%$ of total reduced ${ }^{35} \mathrm{~S}$ formed in surface (0 to $2 \mathrm{~cm}$ ) sediments was recovered as $\mathrm{NAV}^{35} \mathrm{~S}$ which constituted $<5 \%$ of total reduced ${ }^{35} \mathrm{~S}$ below $5 \mathrm{~cm}$ (Fig. 9B). The recovery of reduced ${ }^{35} \mathrm{~S}$ as $\mathrm{DS}\left(\mathrm{D}^{35} \mathrm{~S}\right)$ was uniform with depth, averaging $71 \pm 5 \%$ (Roden \& Tuttle 1992). In contrast, 10 to $30 \%$ of reduced ${ }^{35} \mathrm{~S}$ at Stn DB was recovered as $\mathrm{NAV}^{35} \mathrm{~S}$ throughout the topmost $12 \mathrm{~cm}$ in August (Fig. 9E), and the recovery of $D^{35} S$ was only $31 \pm 6 \%$ (data not shown). In November, recovery of NAV ${ }^{35} \mathrm{~S}$ in the upper $2 \mathrm{~cm}$ of R64 sediment increased to ca $40 \%$ but declined to less than $10 \%$ at depth, whereas at DB, NAV ${ }^{35}$ S accounted for 20 to $60 \%$ of total reduced ${ }^{35} \mathrm{~S}$ throughout the upper $12 \mathrm{~cm}$.

\section{DISCUSSION}

Spatial variation of SR rates in the mid-and lower bay

Organic matter production and deposition patterns indicate that maximum rates of sediment metabolism might be expected in the mid-salinity, transition zone of estuaries (Kemp \& Boynton 1984, Capone \& Kiene 1988). SR and methane production rates in sediments along the salinity gradient of the Hudson River (USA) are consistent with this suggestion (R. Kiene, C. Gilmour \& D. Capone unpubl.). In contrast, rates of anaerobic metabolism appear to be similar in sediments along the salinity gradient of the mid-and lower regions of the Chesapeake Bay estuary. Such high rates of $\mathrm{SR}$ in lower bay sediments seem unusual because their dry weight organic content is severalfold lower than that of mid-bay sediments. However, lower bay sediments are less porous, and therefore the whole sediment organic content is comparable to that of mid-bay sediments. Observations of much greater variation in dry weight organic content than in SR rate have been reported previously for a range of Danish coastal sediments (Jørgensen 1977, Thode-Andersen \& Jørgensen 1989).

High rates of anaerobic metabolism in lower bay sediments probably reflect the combined effects of high primary production rates and a shallow water column $(<15 \mathrm{~m})$, conditions favoring a large input of organic carbon to the sediments (Jørgensen 1983, Nedwell 1984). Although some deposited carbon must support oxygen uptake by macrofauna, meiofauna, and aerobic microorganisms, the contribution of SR to carbon flow is substantial. For example, the lowest summer SR rate we measured in the lower bay (25 mmol m $\left.\mathrm{m}^{-2} \mathrm{~d}^{-1}\right)$ corresponds to a carbon flux of $0.6 \mathrm{~g} \mathrm{C} \mathrm{m}^{-2} \mathrm{~d}^{-1}$, assuming a $2: 1$ ratio of carbon oxidation to $\mathrm{SR}$. This $\mathrm{SR}$ rate can account for a substantial fraction ( $\geq 50 \%)$ of average gross $\mathrm{POC}$ collection rates in surface $(3 \mathrm{~m})$ and midwater $(6 \mathrm{~m})$ sediment traps in the lower bay region during the summer (Wetzel \& Neilson 1989).

Mid-bay deep channel water depths are 10 to $30 \mathrm{~m}$ greater than in the lower bay. This, and the presence of a pronounced mid-depth pycnocline in the mid-bay during the spring and summer (Malone et al. 1986, Tuttle et al. 1987), which would be expected to retard 
Fig. 7. Pore fluid dissolved sulfide concentrations in DB sediments. Symbols as in Fig. $\hat{b}$

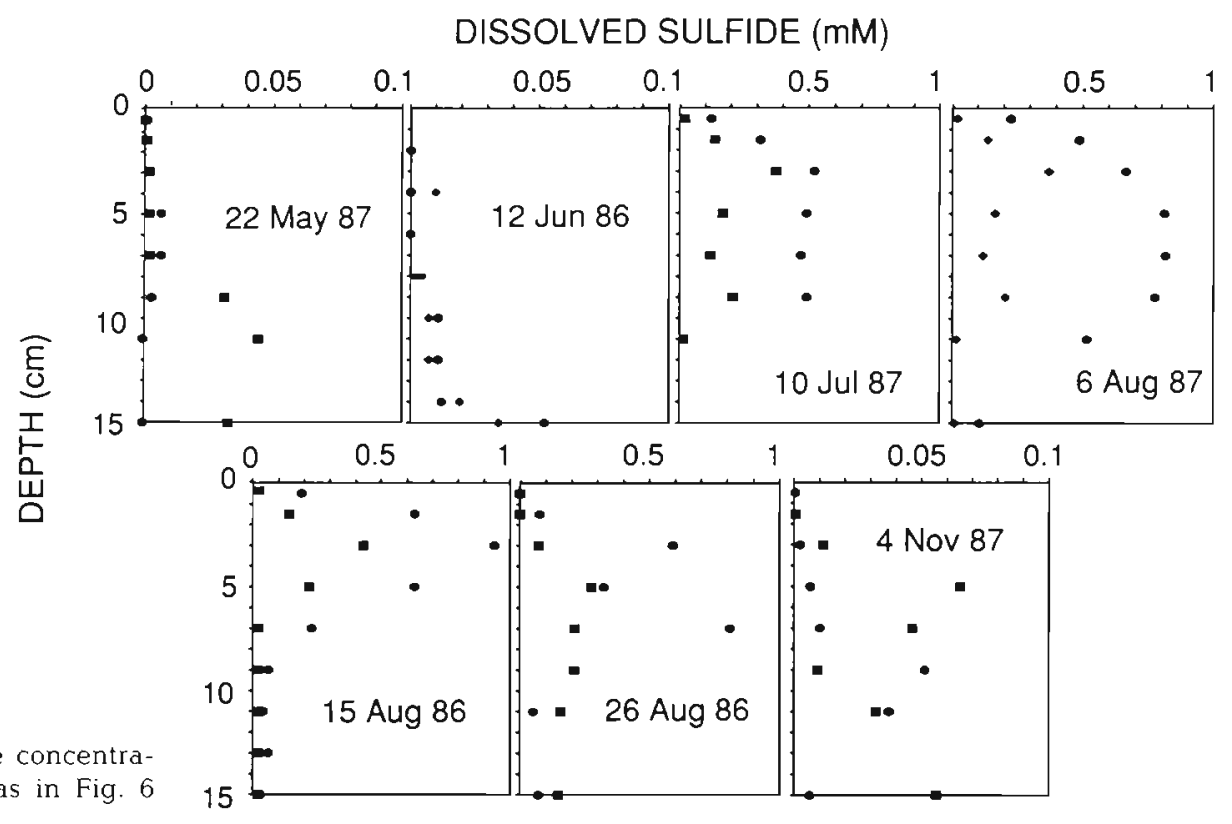

sinking of detrital material to the sediments, suggest that degradation of organic detritus within the water column prior to deposition should be more extensive in the mid-bay deep channel than in the lower bay. This suggestion is supported by the finding that POC becomes less microbially labile as bottom water moves up-bay from Stn 53 to CP3 (Jonas \& Tuttle 1990). However, the occurrence of hypoxic or anoxic conditions in mid-bay bottom waters during the warm season diverts most if not all carbon flow through anaerobic processes, i.e. aerobic respiration is a minor pathway for carbon mineralization in surface sediments. Thus, SR rates in channel sediments at $25 \mathrm{~m}$ (Stn 32) and $40 \mathrm{~m}$ (Stn 24) depths are comparable to those underlying much shallower waters in the midand lower estuary (Table 1).

An exception to this line of reasoning is our results from channel Stn CP3 (25 m depth), where summer SR rates were several-fold lower those found in other mid-and lower bay sediments. This anomaly is likely related to the fact that $\mathrm{CP} 3$ sediments appear to be tidally scoured, as evidenced by the consistent lack of
Fig. 8. Temporal and down-core variation of acid-volatile sulfide (AVS) and non-acidvolatile sulfide (NAVS) concentration ( \pm SD) in sediments at Stns R64 (A and B) and DB (C and D). ( $\mathrm{n}=4$ except R64 April $\mathrm{n}=2$ )

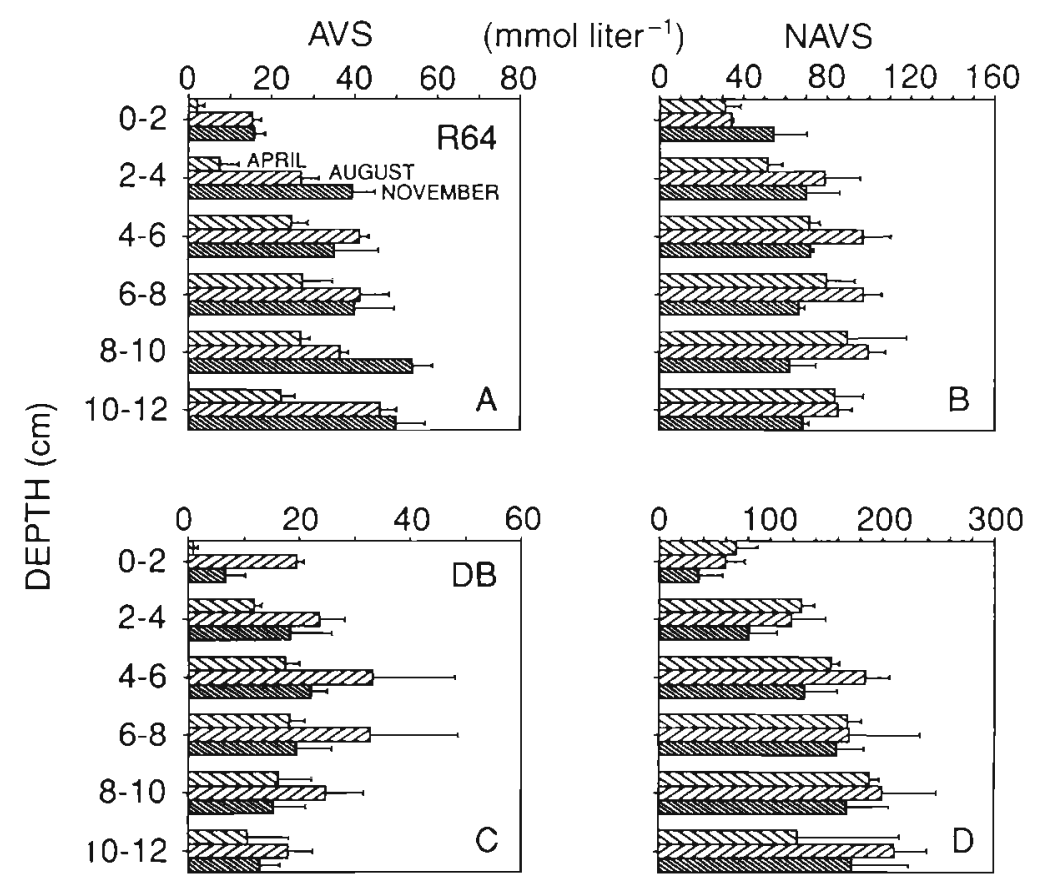


Table 3. Temporal changes in concentrations and pool sizes ( \pm SD) of acid-volatile sulfide in the upper $4 \mathrm{~cm}$ of sediment at Stns R64 and DB. $n=$ no. of cores analyzed on each date

\begin{tabular}{|c|c|c|c|c|c|}
\hline Station & $\begin{array}{l}\text { Depth } \\
\text { interval }\end{array}$ & $\begin{array}{l}\text { Sampling } \\
\text { date }\end{array}$ & $\mathrm{n}$ & $\begin{array}{l}\text { Mean } \\
\text { concentration } \\
(\text { mmol S l-1) }\end{array}$ & $\begin{array}{c}\text { Pool size change } \\
\text { between sampling dates } \\
\left(\mathrm{mol} \mathrm{m}^{-2}\right)\end{array}$ \\
\hline $\mathrm{R} 64$ & $0-2 \mathrm{~cm}$ & $\begin{array}{r}19 \text { Apr } 1989 \\
7 \text { Aug } 1987 \\
4 \text { Nov } 1987\end{array}$ & $\begin{array}{l}2 \\
4 \\
4\end{array}$ & $\begin{array}{r}2.2 \pm 1.8 \\
15.4 \pm 2.2 \\
15.8 \pm 2.7\end{array}$ & $\begin{array}{l}+0.26 \pm 0.10^{b} \\
+0.01 \pm 0.08\end{array}$ \\
\hline R64 & $2-4 \mathrm{~cm}$ & $\begin{array}{l}19 \text { Apr } 1989 \\
7 \text { Aug } 1987 \\
4 \text { Nov } 1987\end{array}$ & $\begin{array}{l}2 \\
4 \\
4\end{array}$ & $\begin{array}{r}7.6 \pm 4.5 \\
27.1 \pm 4.2 \\
39.3 \pm 5.5\end{array}$ & $\begin{array}{l}+0.39 \pm 0.22^{b} \\
+0.44 \pm 0.16^{b}\end{array}$ \\
\hline DB & $0-2 \mathrm{~cm}$ & $\begin{array}{r}25 \text { Apr } 1986 \\
7 \text { Aug } 1987 \\
4 \text { Nov } 1987\end{array}$ & $\begin{array}{l}4 \\
4 \\
4\end{array}$ & $\begin{array}{r}1.0 \pm 0.8 \\
19.5 \pm 1.5 \\
6.8 \pm 3.4\end{array}$ & $\begin{array}{l}+0.37 \pm 0.04^{b} \\
-0.25 \pm 0.09^{b}\end{array}$ \\
\hline DB & $2-4 \mathrm{~cm}$ & $\begin{array}{r}25 \text { Apr } 1986 \\
7 \text { Aug } 1987 \\
4 \text { Nov } 1987\end{array}$ & $\begin{array}{l}4 \\
4 \\
4\end{array}$ & $\begin{array}{l}11.6 \pm 1.5 \\
23.7 \pm 4.6 \\
18.3 \pm 7.6\end{array}$ & $\begin{array}{l}+0.24 \pm 0.11^{b} \\
-0.11 \pm 0.21\end{array}$ \\
\hline \multicolumn{6}{|c|}{$\begin{array}{l}{ }^{a} \text { Pool size change }=\text { change in mean concentration } \times 0.02 \text {; the latter factor converts } \\
\text { concentration in a } 2 \mathrm{~cm} \text { layer of sediment to an areally }\left(1 \mathrm{~m}^{2}\right) \text { integrated pool size. } \\
\text { Error term represents } 95 \% \text { confidence limit }(1-\text { tailed) for the difference between } 2 \\
\text { means, multiplied by } 0.02 \\
{ }^{b} \text { Change in reduced sulfur concentration was significant at the } 95 \% \text { confidence level }\end{array}$} \\
\hline
\end{tabular}

With the exception of Stn CP3, rates of SR were comparable in sediments along the mid-bay transect, all of which are overlain by at least $10 \mathrm{~m}$ of water. It remains to be determined whether similar rates of SR occur in sediments underlying more shallow mid-bay waters. It is likely that such is the case, given the high primary productivity characteristic of the flanks of the mid-bay region (Malone et al. 1986).

\section{Comparison with other systems}

Summer areal SR rates in the majority of mid-and lower Chesapeake Bay sediments examined in this study are in the high range of rates reported for subtidal and intertidal coastal sediments (Table 4). To

a highly porous $(\phi=0.94$ to 0.96 ) surface layer $(0$ to $2 \mathrm{~cm}$ ) that was typical of sediments at other central channel stations. DS concentrations (data not shown) and corresponding upward diffusive DS flux estimates at CP3 in June were 5 to 10 times lower than at R64 in May, verifying that the magnitude of sulfide production in CP3 sediments is significantly lower than in other mid-bay sediments. facilitate direct comparison of sediment metabolic potential, we have adjusted areal rates to a standard temperature of $25^{\circ} \mathrm{C}$ according to an average $Q_{10}$ value of 3 . The highest rates found in Chesapeake Bay sediments are within a factor of 2 of those found in coastal lagoon and mussel bed sediments, and in sediments from other eutrophic coastal waters. This comparison emphasizes the quantitative significance of SR

\section{FRACTION of REDUCED ${ }^{35}$ S RECOVERED as NAVS}

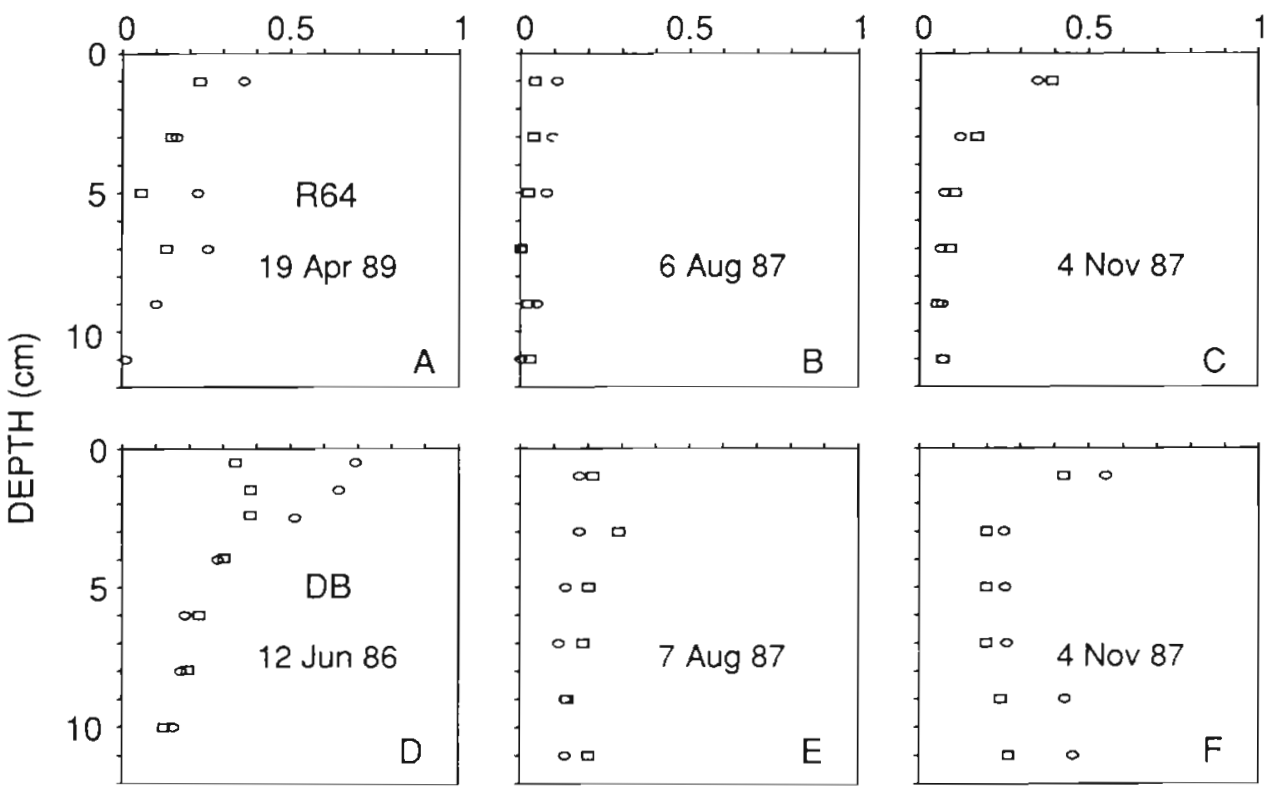

Fig. 9. Relative recovery of reduced ${ }^{35} \mathrm{~S}$ as non-acidvolatile sulfide $\left(\mathrm{NAV}^{35} \mathrm{~S}\right)$ at Stns R64 and DB 


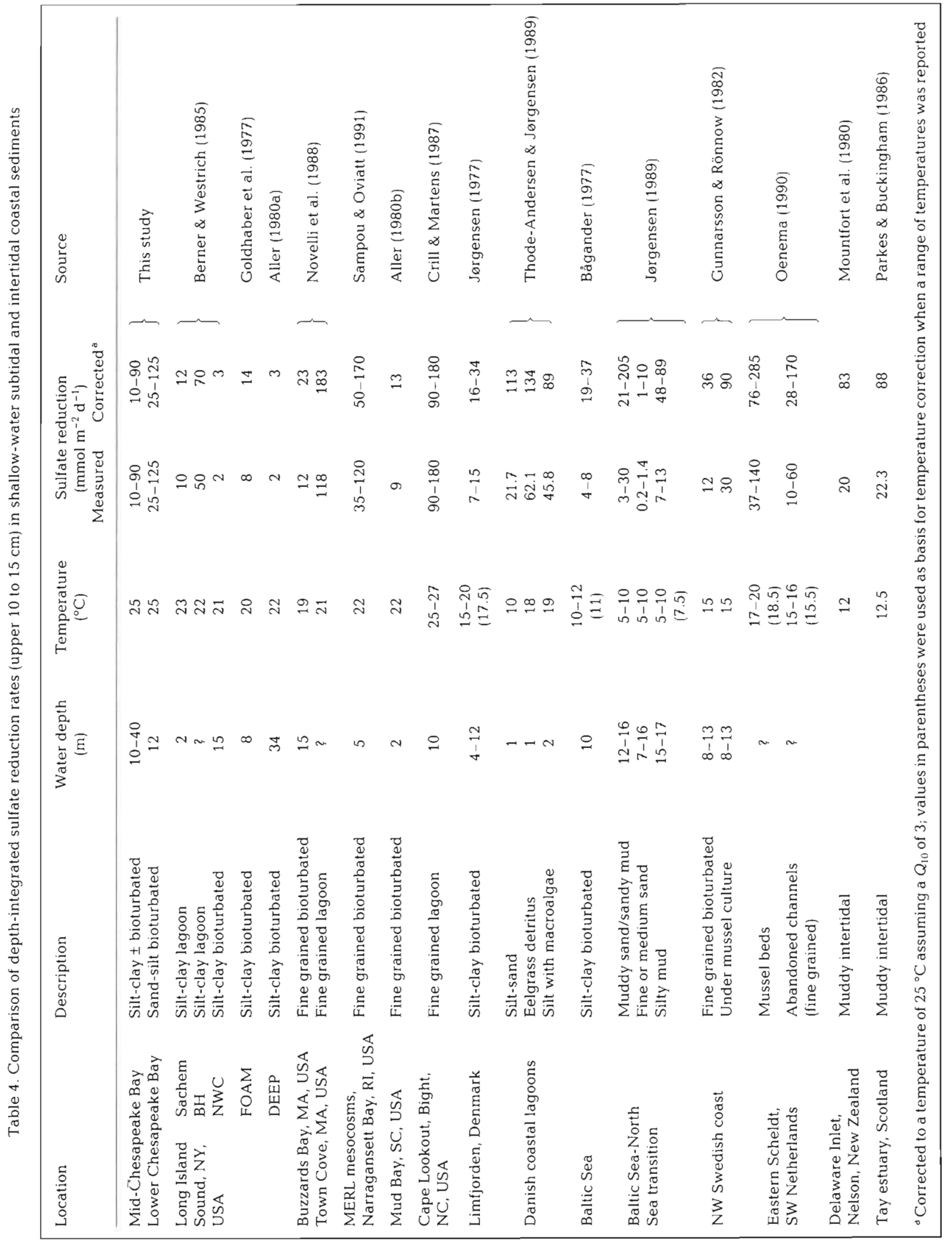


in the sediments over a large area of the shallow, highly productive Chesapeake Bay system.

\section{Sulfate reduction and POC content}

The decrease in SR rate with depth in the top $10 \mathrm{~cm}$ of marine sediments typically reflects a decrease in the availability of degradable organic carbon because sulfate is not usually depleted to limiting concentrations within this interval (Berner 1980). This argument is supported qualitatively by a decrease in dry weight POC content in the upper $10 \mathrm{~cm}$ of sediments along the mid-bay transect (Fig. 10), where sulfate was present at non-limiting concentrations ( $\geq 3 \mathrm{mM}$ ) throughout the spring and summer (data not shown). The estimated ratio of degradable POC (see 'Materials and Methods' and Fig. 10) to total POC decreased from 20 to $30 \%$ at the surface to 1 to $3 \%$ at $10 \mathrm{~cm}$.

The decrease in POC concentration with depth in the upper $10 \mathrm{~cm}$ of sediment was less distinct at Stn DB than at R64 (Fig. 10), and the total degradable POC pool (3.1 mol $\mathrm{C} \mathrm{m}^{-2}$ ) was $50 \%$ higher at $\mathrm{DB}$ than at R64 (2.1 $\left.\mathrm{mol} \mathrm{C} \mathrm{m}^{-2}\right)$. These results agree with higher $\mathrm{SR}$ rates at depth (Figs. 4 \& 5), higher maximum summer areal SR rates (Fig. 3), and a higher seasonally integrated SR rate (Table 2) in DB compared to $\mathrm{R} 64$ sediments. However, the estimated degradable POC pool in CP3 sediments $\left(2.0 \mathrm{~mol} \mathrm{C} \mathrm{m}^{-2}\right)$ was comparable to that estimated for R64 and DB sediments, even though SR rates were 3 to 5 times lower at CP3. Assuming our degradable POC estimation procedure is valid as a first approximation, this suggests that such material in CP3 sediments is metabolized more slowly than that in R64 and DB sediments. Although the lower dry weight POC content of CP3 compared to R64 and DB sediments (Fig. 10) may be related to lower POC lability, the difference in overall POC content (ca $30 \%$ ) is much less than the difference in rates of SR. These comparisons indicate that bulk POC content cannot be used as a quantitative indicator of sediment metabolic potential, even in sediments from the same localized region of the estuary.

\section{Seasonal variation in sulfide production and fate in mid-bay sediments}

Our estimates of the temperature dependence (apparent $E_{\mathrm{a}}$ ) of $\mathrm{SR}$ are in the same range as those determined for other coastal sediments (Vosjan 1974, Jørgensen 1977, Abdollahi \& Nedwell 1979, Aller \& Yingst 1980, King 1988, Klump \& Martens 1989, Mackin \& Swider 1989). Although the Arrhenius equations adequately described the overall seasonal variation of SR rates in mid-bay sediments, they failed to account for the early summer rate maxima observed at Stns R64 and DB (Fig. 3). These high rates were probably related to rapid degradation of fresh organic material deposited during the annual spring diatom bloom (Tuttle et al. 1987, Jonas \& Tuttle 1990). The degradation of this material is expected to shift toward anaerobic pathways with increasing summer temperatures and accelerated microbial metabolism. Maximum SR rates are thus likely to occur just after this shift takes place rather than during the late summer when temperature reaches its annual maximum.

Pronounced temporal variations in the fate of sulfide produced in mid-bay sediments are suggested by DS concentration profiles. During April and May, DS con-

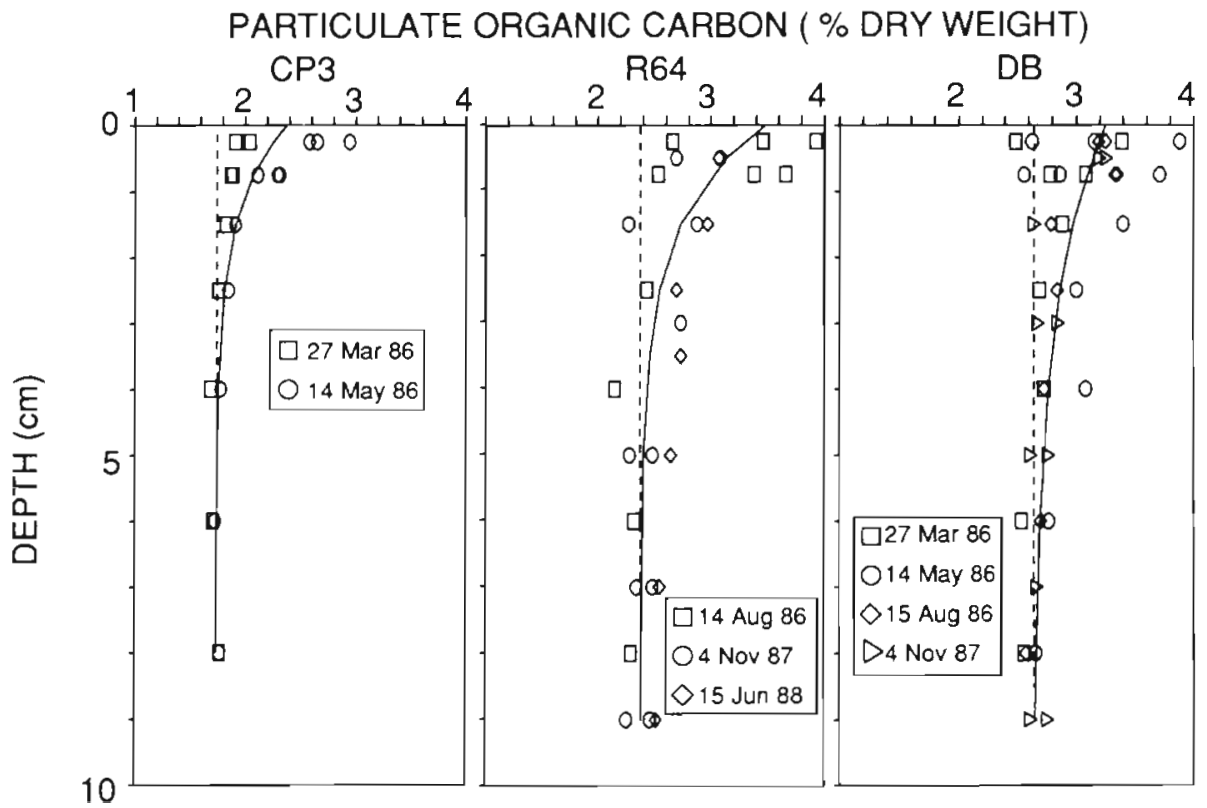

Fig. 10. POC content $(\%$ dry weight) of sediments at Stns CP3, R64, and DB. 1987 data: this study; 1986 and 1988 data: unpubl. results of W. Kemp and J. Cornwell respectively. Solid lines are nonlinear least squares regression fits of the data to the equation $G(x)=$ $\left(G_{0}-G_{L}\right) \exp (-\alpha X)+G_{L}$, where the parameters are described in the text. Dashed lines indicate $G_{L}$ values. The area between the solid and dashed lines represents an estimate of the degradable POC pool in the sediment 
centrations were low or undetectable in the upper few $\mathrm{cm}$ of Stn R64 and DB sediments (Figs. 6 \& 7). Vertical diffusive DS flux at Stn R64 during April (predicted from the DS concentration gradient below $4 \mathrm{~cm}$ ) was estimated at $1 \mathrm{mmol} \mathrm{m}^{-2} \mathrm{~d}^{-1}$, equal to $20 \%$ of depthintegrated SR. Although DS was detected closer to the sediment surface in May than in April, estimated diffusive flux toward the $5 \mathrm{~cm}$ depth horizon was similar (1.2 $\mathrm{mmol} \mathrm{m} \mathrm{m}^{-2} \mathrm{~d}^{-1}$ ), corresponding to only $7 \%$ of depth-integrated SR. Thus the substantial SR rate increase in the upper $5 \mathrm{~cm}$ between April and May ( $>3$-fold) did not result in increased diffusive DS flux toward the sediment-water interface. Similar conclusions are drawn from comparisons of SR rates and pore fluid DS concentrations at Stn DB: the order of magnitude increase in SR rate between April and June (Fig. 3) did not result in a major accumulation of dissolved DS (Fig. 7), and vertical diffusive flux estimates for this time period accounted for only a minor $(<1 \%)$ fraction of total sulfide production.

Reoxidation of DS by oxygen and/or metal oxides might have occurred in the upper several $\mathrm{cm}$ of sediment during the spring and early summer in association with sediment resuspension or particle mixing caused by macrofaunal activity. The recovery of significant portions of reduced ${ }^{35} \mathrm{~S}$ in partially oxidized (i.e. non-acid-volatile) reduced sulfur phases during short-term ${ }^{35} \mathrm{SO}_{4}{ }^{2-}$ reduction experiments indicates that sulfide reoxidation processes were occurring on a time scale of hours (Thode-Anderson \& Jørgensen 1989). The higher recovery of partially oxidized reduced ${ }^{35} \mathrm{~S}$ in DB compared to R64 sediments (Fig. 9), the relatively constant level of $\mathrm{NAV}^{35} \mathrm{~S}$ recovery with depth, and lower ratio of AVS to NAVS (Fig. 8) all suggest that such reoxidation processes were more intense in DB sediments. Consistent with this argument is the observation that maximal SR rates were always found in the topmost $2 \mathrm{~cm}$ of R64 sediments (Fig. 4), whereas a subsurface rate maximum was observed on 3 of 4 dates during April through June at DB (Fig. 5). Whether the subsurface maximum at DB was real (due to inhibition of $\mathrm{SR}$ in the relatively oxidized surface sediments) or an artifact resulting from reoxidation of reduced ${ }^{35} \mathrm{~S}$ to ${ }^{35} \mathrm{SO}_{4}{ }^{2-}$ during incubation is unknown. In either case, the results suggest that surface sediments were more oxidizing at DB than at R64.

Storage of solid-phase iron-sulfide minerals is an alternative mechanism for DS removal from sediment pore fluids. This argument is supported by our esti-

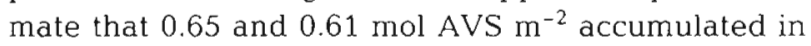
the top $4 \mathrm{~cm}$ of $\mathrm{R} 64$ and DB sediments, respectively, between April and August (Table 3). Potential sources of iron for solid-phase reduced sulfur formation include new sediment deposition as well as ferric iron released during oxidation of iron-sulfides, especially during the winter when SR rates are low (Table 1) and bottom waters oxygen concentrations are maximal.

The estimated reactive ferric iron concentration in R64 sediments in June was ca $15 \mathrm{mmol} \mathrm{I}^{-1}$ in the top $1 \mathrm{~cm}$, decreasing to $<2 \mathrm{mmol} \mathrm{l}^{-1}$ below $5 \mathrm{~cm}$ the depth-integrated ( 0 to $10 \mathrm{~cm}$ ) pool amounted to $0.38 \mathrm{~mol} \mathrm{Fe} \mathrm{m}{ }^{-2}$ (J. Cornwell unpubl.). If AVS accumulation between April and August was due solely to FeS formation, about twice as much iron would be consumed than can be accounted for by the June estimate of the reactive iron pool size in $\mathrm{R} 64$ sediments. This difference is not unreasonable because some FeS accumulation may occur prior to June, and because some sulfide may be consumed in the production of $\mathrm{Fe}^{2+}$ prior to FeS formation. Moreover, given the high variability inherent in measurements of solid-phase sediment species, agreement of the 2 estimates within a factor of 2 is encouraging and consistent with the supposition that something less than 1 mol S per $\mathrm{m}^{2}$ of $\mathrm{R} 64$ sediment is retained as solid-phase reduced sulfur during the spring/summer transition period. Because bottom sediment characteristics are in general similar along a cross-bay transect in this portion of the midbay (Ward 1985), it is reasonable to assume that a comparable amount of reactive ferric iron was available for reduced sulfur storage at Stn DB.

The total amount of sulfate reduced between April and June in R64 sediments (estimated from Arrhenius and time/temperature equations) amounted to ca $0.9 \mathrm{~mol} \mathrm{~S} \mathrm{~m} \mathrm{~m}^{-2}$, enough to account for the estimated AVS accumulation if sulfide reoxidation did not occur. Although some sulfide reoxidation undoubtedly occurs in the spring, it is likely that a large fraction of sulfide produced in the topmost $12 \mathrm{~cm}$ during late spring and early summer is retained in the top $4 \mathrm{~cm}$ of sediment as solid-phase reduced sulfur, because (1) bottom waters become oxygen depleted during this time, thereby retarding sulfide reoxidation and (2) DS formed beneath $4 \mathrm{~cm}$ depth may diffuse into and precipitate within the 0 to $4 \mathrm{~cm}$ layer. Reactive iron remaining in channel sediments at the onset of summer conditions in June should be rapidly transformed to solid-phase reduced sulfur because $>1 \mathrm{~mol}$ of sulfide per $\mathrm{m}^{2}$ sediment could be supplied in $<30 \mathrm{~d}$ at an average summer $S R$ rate of $40 \mathrm{mmol} \mathrm{m} \mathrm{m}^{-2} \mathrm{~d}^{-1}$. Thus phosphate adsorbed to iron oxides in central channel surface sediments could be expected to be released in the early summer, an hypothesis supported by the observation of a distinct seasonal maximum in phosphate release from channel sediments during early July when bottom waters are hypoxic or anoxic (Boynton et al. 1992, Kemp \& Boynton 1992). An early summer phosphate release maximum has also been reported for Cape Lookout Bight (North Carolina, USA) sediments (Klump \& Martens 1981), in which a similar 'titration' of the 
oxidized surface layer occurs during the onset of summer conditions.

Benthic chamber and radiotracer estimates of DS flux indicated that a large fraction (ca $70 \%$ ) of DS produced in the sediment is released to anoxic bottom waters in August (Roden \& Tuttle 1992), It appears that DS accumulation in sediment pore fluids accounts for only a minor fraction $(\leq 10 \%)$ of summertime sulfide production in central channel sediments. Likewise, although DS was more abundant between 5 and $10 \mathrm{~cm}$ in R64 sediments in October and November compared to April and May, this accumulation represented only a minor fraction ( $<5 \%$ ) of total sulfide production during the warm season.

Summertime DS concentrations in DB sediments were much higher than those in the spring (Fig. 7), but this DS accumulation $\left(<0.05 \mathrm{~mol} \mathrm{~S} \mathrm{~m}{ }^{-2}\right.$ ) accounted for only a small portion $(<2 \%)$ of total sulfide production from April to August ( $3.5 \mathrm{~mol} \mathrm{~S} \mathrm{~m}{ }^{-2}$ ). AVS accumulation in the top $4 \mathrm{~cm}$ of $\mathrm{DB}$ sediment accounted for only $17 \%$ (0.6 mol S m${ }^{-2}$; Table 3 ) of April to August sulfide production. If the apparent April to August increase in AVS concentration in the 4 to $8 \mathrm{~cm}$ depth interval (Fig. 8C) is assumed to represent net solid-phase sulfide accumulation, the seasonal sulfide storage estimate increases to $1.2 \mathrm{~mol} \mathrm{~m} \mathrm{~m}^{-2}$ sediment. This quantity of reduced sulfur is still only $34 \%$ of total April to August sulfide production, suggesting that the majority of sulfide produced at Stn DB was lost from the sediment during this time period. Whereas direct release of DS to anoxic bottom waters is an important mechanism of sulfide loss from central channel sediments, reoxidation at the sediment water interface or within macrofaunal burrow tubes is likely an important mechanism of sulfide removal from DB sediments.

\section{Role of sulfur cycling in summertime mid-bay sediment carbon and oxygen metabolism}

Hypoxic or anoxic conditions in mid-bay channel bottom waters throughout the summer months limit the magnitude of direct sediment oxygen consumption (Boynton et al. 1991, Kemp et al. 1992). When oxygen does penetrate into bottom waters (in association with lateral seiching of the mid-water pycnocline or storm events; Malone et al. 1986, Tuttle et al. 1987), reduced sulfur species which have accumulated in bottom waters and surface sediments may be rapidly oxidized. Extremely high oxygen consumption rates have in fact been observed in anoxic central channel cores in which the oxygen content of the overlying water was either accidentally or intentionally elevated at the beginning of the incubation period (Boynton et al.
1988, Sampou \& Cornwell 1988). During the summer, sulfur cycling undoubtedly dominates central channel sediment carbon and oxygen metabolism.

Rates of sediment oxygen consumption (SOC) measured at Stn DB during August 1986 and 1987 averaged $50 \pm 5 \mathrm{mmol} \mathrm{O}_{2} \mathrm{~m}^{-2} \mathrm{~d}^{-1}$ (Kemp et al. 1992, Kemp unpubl.). The average August SR rate in the same 2 years was $51 \pm 16 \mathrm{mmol} \mathrm{S} \mathrm{m}^{-2} \mathrm{~d}^{-1}(\mathrm{n}=8$ cores $)$. If we assume, based on the estimates of reduced sulfur storage given above, that somewhere between and 17 and $34 \%$ of sulfide production during August was stored as solidphase reduced sulfur and that the balance was being reoxidized by oxygen according to a $2: 1$ stoichiometry (Jørgensen 1977), SOC rates should have been 40 to $70 \%$ greater than the measured rates. This discrepancy either calls into question the accuracy of the SR and/or SOC rate estimates, or is suggestive of higher summertime sulfide storage.

Our SR measurements at Stn DB are probably not erroneously high. Estimates of $\mathrm{CO}_{2}$ release from $\mathrm{DB}$ sediments made during August 1986 (127 $\pm 21 \mathrm{mmol}$ $\mathrm{m}^{-2} \mathrm{~d}^{-1}, \mathrm{n}=5 ;$ P. Sampou unpubl.) agreed within experimental uncertainty with those predicted from our SR rates $\left(102 \pm 32 \mathrm{mmol} \mathrm{m} \mathrm{m}^{-2} \mathrm{~d}^{-1}\right.$, assuming a $2: 1$ ratio of carbon oxidation coupled to SR). On the other hand, SOC measurements obtained from stirred shipboard core and benthic dome incubations could be underestimates due to lower turbulence during incubation relative to in situ conditions. Sediment trap collections at $\operatorname{Stn} \mathrm{DB}$ provide evidence of substantial rates of surface sediment resuspension (Boynton et al. 1988, 1991), whereas sediment resuspension did not occur during the oxygen flux measurements. Unfortunately, available data do not allow speculation about the possible influence of resuspension on in situ rates of SOC.

An alternative explanation for the above discrepancy is that $50 \%$ or more of August sulfide production accumulated in DB sediments. During August, only $31 \pm 6 \%$ ( $n=122-\mathrm{cm}$ core segments) of the reduced end products of ${ }^{35} \mathrm{SO}_{4}{ }^{2-}$ reduction in DB sediments was recovered as DS after an $8 \mathrm{~h}$ incubation period, suggesting that a large fraction of sulfide production in the topmost $12 \mathrm{~cm}$ of sediment was partitioned into solidphase reduced sulfur compounds. However, transfer of ${ }^{35} \mathrm{~S}$ from DS to solid-phase $\mathrm{S}^{\circ}$ or FeS via isotope exchange (Fossing \& Jørgensen 1990), rather than a net accumulation of solid-phase reduced sulfur, could have been at least partly responsible for this result. Furthermore, accumulation of solid-phase reduced ${ }^{35} \mathrm{~S}$ during short-term radiotracer incubations does not rule out the possibility that a continuous cycle of solidphase reduced sulfur formation and reoxidation occurs in situ on time scales longer than those used for the ${ }^{35} \mathrm{SO}_{4}{ }^{2-}$ reduction assays. 
Nevertheless, if we assume that ca $30 \%$ of total sulfate reduction resulted in net release of DS to sediment pore fluids, then the DS pool in the upper $12 \mathrm{~cm}$ of sediment (ca $60 \mathrm{mmol} \mathrm{m}^{-2}$ ) would have been turning over every 4 d during August. Such a rapid rate of turnover suggests that the balance between DS production and loss from sediment pore fluids could have approximated a steady state on a time scale of weeks during the summer. Assuming that this was so at the time of our measurements during August, we estimate a DS loss rate amounting to $0.3 \times 51=15 \mathrm{mmol} \mathrm{S} \mathrm{m}^{-2}$ $\mathrm{d}^{-1}$. This must be regarded as a minimum estimate, given the possible sources of error discussed above. Even so, the corresponding estimate of SOC coupled to sulfide reoxidation $\left(2 \times 15=30 \mathrm{mmol} \mathrm{m}^{-2} \mathrm{~d}^{-1}\right)$ is equal to $60 \%$ of the measured SOC rate. Furthermore, if the balance of $\mathrm{SOC}\left(20 \mathrm{mmol} \mathrm{O}_{2} \mathrm{~m}^{-2} \mathrm{~d}^{-1}\right)$ were coupled to aerobic carbon respiration (carbon flux of $20 \mathrm{mmol} \mathrm{C} \mathrm{m} \mathrm{C}^{-1}$ ), it could account for no more than $[20 /\{(51 \times 2)+20\}] \times 100=16 \%$ of total sediment carbon metabolism.

Despite uncertainties in the above calculations, it is evident that, as at Stn R64, sulfur cycling dominated carbon metabolism and oxygen consumption by DB sediments during August. Similar conclusions have been drawn from summer measurements of SR and SOC in Cape Lookout Bight (Chanton et al. 1987), Flax Pond (Long Island Sound, New York, USA) marsh flat (Mackin \& Swider 1989), and eutrophic Narragansett Bay (Rhode Island, USA) mesocosm sediments (Sampou \& Oviatt 1991) in which metabolic rates were about twice those at Stn DB. Our results reinforce the assertion of Sampou \& Oviatt (1991) that, because of the potential for transient solid-phase reduced sulfur storage, it may not be appropriate to extrapolate rates of sediment carbon degradation from SOC measurements over short time scales in organic-rich coastal sediments.

Table 5. Reduced sulfur burial and retention estimates for 3 mid-bay stations

\begin{tabular}{|c|c|c|c|c|c|}
\hline Station & $\begin{array}{c}\text { Mass } \\
\text { sedimentation } \\
\text { rate } \\
\left(\mathrm{g} \mathrm{m}^{-2} \mathrm{yr}^{-1}\right)\end{array}$ & $\begin{array}{l}\text { Reduced sulfur } \\
\text { concentration } \\
\text { below } 4 \mathrm{~cm} \mathrm{depth} \\
\left(\mathrm{mol} \mathrm{S} \mathrm{g}^{-1}\right)\end{array}$ & $\begin{array}{l}\text { Reduced sulfur } \\
\text { burial rate } \\
\left.\text { (mol S } \mathrm{m}^{-2} \mathrm{yr}^{-1}\right)\end{array}$ & $\begin{array}{l}\text { Annual sulfate } \\
\text { reduction rate } \\
\left.\text { (mol S } \mathrm{m}^{-2} \mathrm{y}^{-1}\right)\end{array}$ & $\begin{array}{c}\text { Percent } \\
\text { retention }\end{array}$ \\
\hline CP3 & 930 & 0.00041 & 0.28 & 1.4 & 29 \\
\hline $\mathrm{R} 64$ & 1860 & 0.00043 & 0.60 & 5.3 & 15 \\
\hline DB & 3000 & 0.00043 & 1.3 & 7.2 & 18 \\
\hline \multicolumn{6}{|c|}{$\begin{array}{l}{ }^{2} \text { The mass sedimentation rate at } \mathrm{Stn} \text { R } 64 \text { was derived from sediment trap data (Boynton et } \\
\text { al. 1988). For Stn DB, the mass deposition rate determined from }{ }^{210} \mathrm{~Pb} \text { and }{ }^{239.240} \mathrm{Pu} \text { profiles } \\
\text { at a nearby location (Officer et al. 1984, Stn } 834 \mathrm{G} \text { ) was assumed. A deposition rate half that } \\
\text { estimated for Stn R64 was selected arbitrarily for Stn CP3 to account for the deeper water } \\
\text { column at CP3 ( } 25 \mathrm{~m} \text { ) compared to } \mathrm{R} 64(16 \mathrm{~m} \text { ), and for the observation that CP3 sediments } \\
\text { appeared to be tidally scoured } \\
\text { b Mass sedimentation rate } \times \text { reduced sulfur concentration } \\
\text { (Reduced sulfur burial rate/annual sulfate reduction rate) } \times 100\end{array}$} \\
\hline
\end{tabular}

\section{Permanent reduced sulfur retention}

Average solid-phase reduced sulfur concentrations at depth in the sediment, annual reduced sulfur burial rates, annual SR rates, and estimated reduced sulfur retention at each of the mid-bay transect stations are given in Table 5 . The annual SR rate estimates represent minimum values, because (1) only 9 mo of the year were considered in the calculations (see Table 2), (2) early summer rate maxima at Stns R64 and DB were not accounted for by the Arrhenius equations (see above), and (3) SR occurring beneath $12 \mathrm{~cm}$ depth was not included. Even so, most of the sulfide formed on an annual basis is not retained in the sediment. This agrees with studies in Danish coastal sediments (Jørgensen 1977), subtidal Long Island Sound sediments (Berner \& Westrich 1985), and Long Island Sound marsh flat sediments (Swider \& Mackin 1989). Significantly higher sulfide retention estimates reported for some coastal lagoon sediments (Berner \& Westrich 1985. Chanton et al. 1987) are probably related to higher rates of iron input (associated with more rapid sediment accumulation and/or more iron-rich source material) compared to other coastal sediments, including those in the mid-Chesapeake Bay.

Given the substantial variation in SR rates in the midbay transect sediments, the similarity of their dry weight reduced sulfur content indicates that the availability of iron rather than sulfide production rate limits reduced sulfur burial. This is supported by the finding that very little reactive iron can be extracted from sediment at depths below which solid-phase reduced sulfur accumulation does not occur. For example, the amount of oxalate extractable ferric iron at depth in R64 sediments (ca $15 \mathrm{mmol} \mathrm{l}^{-1}$; J. Cornwell unpubl.) is only about $20 \%$ of the iron accounted for in solid-phase reduced sulfur compounds (AVS and NAVS were assumed to be $\mathrm{FeS}$ and $\mathrm{FeS}_{2}$ respectively). Thus, most of the iron oxide deposited to mid-bay sediments is transformed ultimately into iron-sulfide minerals. Similar results have been reported for sediments at a $9 \mathrm{~m}$ deep station in Long Island Sound (Canfield 1989).

Due to uncertainty in the mass sedimentation rate at Stn CP3, we can make only a first approximation of the degree of sulfide retention at this location (Table 5). Assum- 
ing that the sedimentation rate at CP3 is comparable to that at R64 within a factor of 2, the large difference in total SR rate ( 4 -fold) between the 2 stations leads to a higher sulfide retention estimate for Stn CP3. However, the difference in sulfide retention amounts to only $15 \%$ of total SR, suggesting that the magnitude of sulfide loss from mid-bay sediments is controlled mainly by the rate of SR rather than by the rate of reduced sulfur burial. From the data in Table 5 we estimate that sulfide reoxidation accounts for an annual sediment oxygen demand of at least 2, 9 and $12 \mathrm{~mol} \mathrm{O}_{2} \mathrm{~m}^{-2} \mathrm{yr}^{-1}$ at Stns CP3, R64, and $\mathrm{DB}$, respectively.

On a dry weight basis, fine-grained mid-bay muds had 2 to 6 times greater reduced sulfur content (1 to $3 \%$ ) than the sand-silt sediments of the lower bay $(0.2$ to $0.5 \%$ ). This difference is not unexpected because most of the iron required for solid-phase reduced sulfur formation in marine sediments is associated with the fine-grained clay fraction (Cornwell et al. 1988). Furthermore, reduced sulfur reoxidation associated with sediment particle mixing and pore water irrigation caused by macrofaunal activity is probably more extensive in the lower bay than in the mid-bay, particularly relative to mid-bay channel sediments overlain by hypoxic or anoxic water during the summer. DS was not detectable in Stn LB1 and LB3 sediments and was $<0.1 \mathrm{mM}$ in Stn LB2 sediments during the summer (Fig. 11A). The ratio of AVS to NAVS concentration in lower bay sediments was $<0.1$. Despite these differences, whole sediment concentrations of solid-phase reduced sulfur (Fig. 11C) were of the same order of magnitude $\left(10^{2} \mathrm{mmol}^{-1}\right)$ as those in the mid-bay. This reflects intensive rates of $S R$ in lower bay sediments (Fig. 11B) and the presence of surface sediment ferric
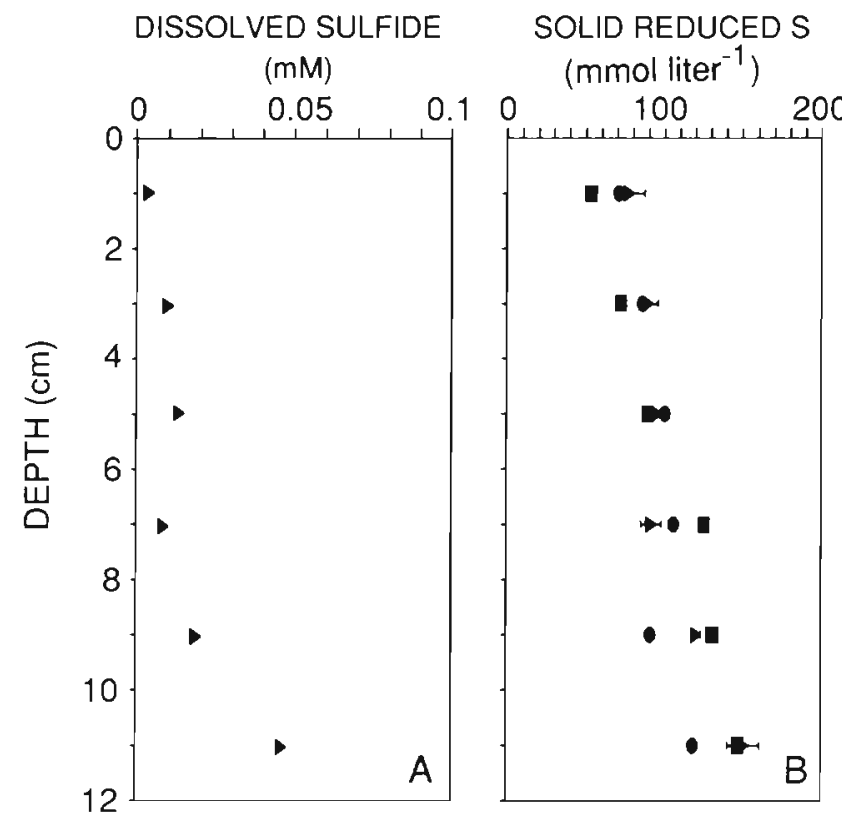

iron concentrations comparable to mid-bay sediments on a whole sediment basis (J. Cornwell unpubl.). If annual rates of SR in the lower bay sediments investigated in this study are comparable to those in the most metabolically active mid-bay sediments $(5$ to $10 \mathrm{~mol} \mathrm{~S}$ $\mathrm{m}^{-2} \mathrm{yr}^{-1}$ ), the ratio of permanent sulfide burial to total SR is probably similar to that estimated for those midbay sediments, i.e. $<20 \%$.

Acknowledgements. This research was supported by National Science Foundation Grant OCE-8208032 and NOAA-Sea Grant Project R/DO-9 (both awarded to J.H.T). We thank J. M. Barnes, P. A. Sampou, W. M. Kemp, and the captains and crew of the RV 'Aquarius' and RV 'Orion' (Chesapeake Biological Laboratory, University of Maryland) for assistance during sediment sampling in the mid-Chesapeake Bay region. We also thank D. L. Rice (Chief Scientist) and the captain and crew of the RV 'Ridgley Warfield' (Chesapeake Bay Institute, Johns Hopkins University), and J C. Means (Chief Scientist) and the captain and crew of the RV 'Ferrel' (NOAA, Norfolk, Virginia) for the opportunity to collect sediment samples in the lower bay region. We gratefully acknowledge W. M. Kemp, W. R. Boynton, and J. C. Cornwell for permission to quote unpublished data. M. M. Weir assisted with sample processing in the laboratory. This is Contribution No. 2371 of the Center for Environmental and Estuarine Studies of the University of Maryland System.

\section{LITERATURE CITED}

Abdollahi, H., Nedwell, D. B. (1979). Seasonal temperature as a factor influencing bacterial sulfate reduction in a salt marsh sediment. Microbiol. Ecol. 5: 73-79

Albert, D. (1984). Improved techniques for measurement of sulfate reduction and pyrite formation rates in sediments. EOS 45: 906

Aller, R. C. (1980a). Diagenetic processes near the sediment-

\section{SULFATE REDUCTION}

(mmol liter ${ }^{-1} \mathrm{~d}^{-1}$ )

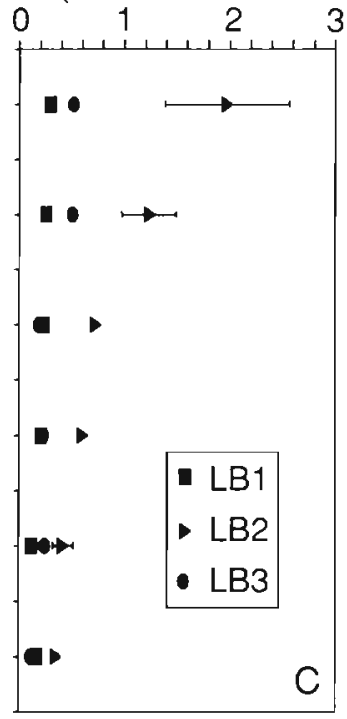

Fig. 11. Pore fluid dissolved sulfide concentrations (A), solid-phase reduced sulfur concentrations (B), and sulfate reduction rates $(\mathrm{C})$ in sediments at 3 locations in the lower Chesapeake Bay. Error bars represent the range of duplicate samples at LB2 
water interface of Long Island Sound. II. Fe and Mn. In: Saltzman, B. (ed.) Estuarine physics and chemistry: studies in Long Island Sound, Advances in geophysics, Vol. 22. Academic Press, New York, p. 351-415

Aller, R. C. (1980b). Quantifying solute distributions in the bioturbated zone of marine sediments by defining an average microenvironment. Geochim. cosmochim. Acta 44: $1955-1965$

Aller, R. C., Yingst, J Y (1980). Relationships between microbial distributions and the anaerobic decomposition of organic matter in surface sediments of Long Island Sound, USA. Mar. Biol. 56: 29-42

Bågander, L. E. (1977). In situ studies of bacterial suflate reduction at the sediment-water interface. Ambio spec. Rep. 5: $147-155$

Berner, R. A. (1980). Early diagenesis. Princeton University Press, Princeton

Berner, R. A., Westrich, J. T. (1985). Bioturbation and the early diagenesis of carbon and sulfur. Am. Sci. 285: 193-206

Boynton, W. R., Garber, J., Barnes, J. M., Kemp, W. M. (1991). Chesapeake Bay water quality monitoring program, ecosystem processes component, Level 1 Report No. 8. UMCEES Ref. No. 91-110CBL. Univ, of Maryland, Center for Environmental and Estuarine Studies, Chesapeake Biological Laboratory, Solomons

Boynton, W. R., Kemp, W. M., Barnes, J. M., Cowan, J. L. W., Stammerjohn, S. E., Matteson, L. L., Rohland, F. M., Marvin, M. (1992). Long-term characteristics and trends of benthic oxygen and nutrient fluxes in the Maryland portion of Chesapeake Bay. In: Mihursky, J. A., Chaney, A. (eds.) New perspectives in the Chesapeake system. Chesapeake Research Consortion Publication No. 137 , Solomons, p. 339-354

Boynton, W. R., Kemp, W. M., Garber, J., Barnes, J. M., Robertson, L. L., Watts, J. L. (1988). Chesapeake Bay water quality monitoring program, ecosystem processes component, Level 1 Report No. 5. UMCEES Ref. No. 88-69CBL. Univ. of Maryland, Center for Environmental and Estuarine Studies, Chesapeake Biological Laboratory, Solomons

Canfield, D. E. (1989). Reactive iron in marine sediments. Geochim. cosmochim. Acta 53: 619-632

Capone, D. G., Kiene, R. P. (1988). Comparison of microbial dynamics in freshwater and marine environments: contrasts in anaerobic carbon catabolism. Limnol. Oceangr. 33: $725-749$

Chanton, J. P., Martens, C. S., Goldhaber, M. B. (1987). Biogeochemical cycling in an organic-rich coastal marine basin. 7. Sulfur mass balance, oxygen uptake, and sulfide retention. Geochim. cosmochim. Acta 51: $1187-1199$

Cornwell, J. C., Lin, S., Huerta-Diaz, M., Morse, J. W. (1988). Iron sulfide formation and diagenesis in the sediments of Laguna Madre and adjacent bays. EOS 68: 1710

Crill, P. M., Martens, C. S. (1987). Biogeochemical cycling in an organic-rich coastal marine basin. 6. Temporal and spatial variations in sulfate reduction rates. Geochim. Cosmochim. Acta. 51: 1175-1186

Fossing, H., Jorgensen, B. B. (1990). Isotope exchange reactions with radiolabeled sulfur compounds in anoxic seawater. Biogeochemistry 9: 223-245

Goldhaber, M. B., Aller, R. C., Cochran, J. K., Martens, C. S. Berner, R. A. (1977). Sulfate reduction, diffusion, and bioturbation in Long Island Sound sediments: report of the FOAM group. Am. Sci. 277: 193-237

Gunnarsson, L. A. H., Rönnow, P. H. (1982). Interrelationships between sulfate reducing and methane producing bac- teria in coastal sediments with intense sulfide production. Mar. Biol. 69: 121-128

Howarth, R. W. (1984). The ecological significance of sulfur in the energy dynamics of salt marsh and coastal marine sediments. Biogeochemistry 1: 5-27

Howes, B. L., Dacey, J. W. H., King, G. M. (1984). Carbon flow through oxygen and sulfate reduction pathways in salt marsh sediments. Limnol. Oceanogr. 29: 1037-1051

Jonas, R. B., Tuttle, J. H. (1990). Bacterioplankton and organic carbon dynamics in the lower mesohaline Chesapeake Bay. Appl. environ. Microbiol. 56: 747-757

Jorgensen, B. B. (1977). The sulfur cycle of a coastal marine sediment (Limfjorden, Denmark). Limnol. Oceanogr 28 : $814-822$

Jorgensen, B. B. (1978a). A comparison of methods for the quantification of bacterial sulfate reduction in coastal marine sediments 1 . Measurement with radiotracer techniques. Geomicrobiol, J. 1: 11-28

Jørgensen, B. B. (1978b). A comparison of methods for the quantification of bacterial sulfate reduction in coastal marine sediments II. Calculations from mathematical models. Geomicrobiol. 1: 29-51

Jorgensen, B. B. (1982). Mineralization of organic matter in the seabed - the role of sulphate reduction. Nature 269: $643-645$

Jorgensen, B. B. (1983). Processes at the sediment water interface. In: Bolin, B., Cook, R. B. (eds.) The major biogeochemical cycles and their interactions. Wiley and Sons, New York, p. 477-509

Jorgensen, B. B. (1989). Sulfate reduction in marine sediments from the Baltic Sea-North Sea transition. Ophelia 31: 1-15

Jorgensen, B. B., Fenchel, T (1974). The sulfur cycle of a marine sediment model system. Mar. Biol. 24: 189-201

Kemp, W. M., Boynton, W. R. (1984). Spatial and temporal coupling of nutrient inputs to estuarine primary production: the role of particulate transport and decomposition. Bull. mar. Sci. 35: 242-247

Kemp, W. M., Boynton, W. R. (1992). Benthic-pelagic interactions: nutrient and oxygen dynamics. In: Smith, D., Leffler, M., Mackiernan, G. (eds.) Oxygen dynamics in Chesapeake Bay. Maryland Sea Grant, College Park, p. 149-221

Kemp, W. M., Sampou, P., Caffrey, J., Mayer, M., Henriksen, K., Boynton, W. R. (1991). Nitrogen cycling in sediments of a coastal plain estuary: ammonium recycling versus denitrification. Limnol. Oceanogr. 35: 1545-1563

Kemp, W. M., Sampou, P. A., Garber, J., Tuttle, J. H., Randall, W. T., Boynton, W. R. (1992). Seasonal depletion of oxygen from bottom waters of Chesapeake Bay: roles of benthic and planktonic respiration and physical exchange processes. Mar. Ecol. Prog. Ser. 85: 137-152

King, G. M. (1988). Patterns of sulfate reduction and the sulfur cycle in a South Carolina salt marsh. Limnol. Oceanogr 33: $376-390$

Klump, J. V., Martens, C. S. (1981). Biogeochemical cycling in an organic rich coastal marine basin. II. Nutrient sediment-water exchange processes. Geochim. cosmochim. Acta. 45: 101-121

Klump, J. V., Martens, C. S. (1989). The seasonality of nutrient regeneration in an organic-rich coastal sediment: kinetic modeling of changing pore-water nutrient and sulfate distributions. Limnol. Oceanogr. 34: 559-577

Li, Y. Y., Gregory, S. (1974). Diffusion of ions in sea water and in deep-sea sediments. Geochim. cosmochim. Acta. 38: $703-714$

Mackin, J. E., Swider, K. T (1989). Organic matter decomposition pathways and oxygen consumption in coastal marine sediments. J. mar. Res. 47:681-716 
Malone, T C., Kemp, W. M., Ducklow, H. W., Boynton, W. R., Tuttle, J. H., Jonas, R. B. (1986). Lateral variation in the production and fate of phytoplankton in a partially stratified estuary. Mar. Ecol. Prog. Ser. 32: 149-160

Mountfort, D. O., Asher, R. A., Mays, E. L., Tiedje, J. M (1980). Carbon and electron flow in mud and sandflat intertidal sediments at Delaware Inlet, Nelson, New Zealand. Appl. environ. Microbiol. 39: 686-694

Murray, J. W., Grundmanis, V., Smethie, W. M. Jr (1978) Interstitial water chemistry in the sediments of Sannich Inlet. Geochim. cosmochim. Acta. 42: 1011-1026

Nedwell, D. B. (1984). The input and mineralization of organic carbon in anaerobic aquatic sediments. In: Marshall, K. C. (ed.) Advances in microbial ecology, Vol. 7. Plenum Press, New York, p. 93-101

Novelli, P. C., Michelson, A. R., Scranton, M. I., Banta, G. T. Hobbie, J. E., Howarth, R. W. (1988). Hydrogen and acetate cycling in two sulfate-reducing sediments: Buzzards Bay and Town Cove, Mass. Geochim. cosmochim. Acta 52: 2477-2486

Oenema, O. (1990). Sulfate reduction in fine-grained sediments in the Eastern Scheldt, southwest Netherlands. Biogeochemistry 9: 53-74

Officer, C. B., Lynch, D. R., Setlock, G. H., Helz, G. R. (1984). Recent sedimentation rates in Chesapeake Bay. In: Kennedy, V. S. (ed.) The estuary as a filter. Academic Press, New York, p. 131-158

Parkes, R. J., Buckingham, W. J. (1986). The flow of organic carbon through aerobic respiration and sulfate reduction in inshore marine sediments. In: Meyusar, F., Gantar, M. (eds.) Perspectives in microbial ecology: proceedings of the 40 th International Symposium on Microbial Ecology. Slovac Society for Microbiology, Ljubljanu, Yugoslavia, p. 617-624

Rice, D. L. (1986). Early diagenesis in bioadvective sediments relationships between the diagenesis of beryllium- 7 , sediment reworking rates, and the abundance of conveyorbelt deposit-feeders. J. mar. Res. 44: 149-184

Roden, E. E., Tuttle, J. H. (1992). Sulfide release from

This article was submitted to the editor estuarine sediments underlying anoxic bottom water. Limnol. Oceanogr. 37: 725-738

Sampou, P., Cornwell, J. (1988). Benthic sulfide flux and its role in maintaining anoxia in the mesohaline bottom waters of Chesapeake Bay. EOS 69: 1103

Sampou, P., Oviatt, C. A. (1991). Seasonal patterns of sedimentary carbon and anaerobic respiration along a simulated eutrophication gradient. Mar. Ecol. Prog. Ser. 72: $271-282$

Swider, K. T., Mackin, J. E. (1989). Transformations of sulfur compounds in marsh-flat sediments. Geochim. cosmochim. Acta. 53: 2311-2323

Thode-Andersen, S., Jørgensen, B. B. (1989). Sulfate reduction and the formation of ${ }^{35} \mathrm{~S}$-labeled $\mathrm{FeS}, \mathrm{FeS}_{2}$ and $\mathrm{S}^{\circ}$ in coastal marine sediments. Limnol. Oceanogr. 34: 793-806

Truper, H. G., Schlegel, H. G. (1964). Sulfur metabolism in Thiorhodacea 1. Antonie van Leeuwenhoek. 30: 225-238

Tuttle, J. H., Jonas, R. B., Malone, T. C. (1987). Origin, development and significance of Chesapeake Bay anoxia. In: Majumdar, S. K., Hall, L. W., Herbert, M. A. (eds.) Contaminant problems and management of living Chesapeake Bay resources. Pennsylvania Academy of Sciences, Phillipsburg, p. $442-472$

Vosjan, J. H. (1974). Sulfate in water and sediment of the Dutch Wadden Sea. Neth. J. Sea Res. 8: 208-213

Ward, L. G. (1985). The influence of wind waves and tidal currents on sediment resuspension in middle Chesapeake Bay. Geo-Marine Lett. 5: 71-75

Wetzel, R., Neilson, B. (1989). Sediment processes monitoring annual report for calender year 1988. Special Report No. 301 in Applied Marine Science and Ocean Engineering. Virginia Institute of Marine Science, College of William and Mary, Gloucester Point

Zhabina, N. N., Volkov, I. I. (1978). A method of determination of various sulfur compounds in sea sediment and rocks. In: Krumbein, W. E. (ed.) Environmental biogeochemistry and geomicrobiology, Vol. 3. Ann Arbor Sci. Publ., Ann Arbor, p. $735-746$

Manuscript first received: July 22, 1991

Revised version accepted: December 10,1992 